\title{
Time discounting and the body mass index
}

Citation for published version (APA):

Borghans, L., \& Golsteyn, B. H. H. (2005). Time discounting and the body mass index. Researchcentrum voor Onderwijs en Arbeidsmarkt, Faculteit der Economische Wetenschappen. ROA Research Memoranda No. 5E https://doi.org/10.26481/umaror.200505E

Document status and date:

Published: 01/01/2005

DOI:

10.26481/umaror.200505E

Document Version:

Publisher's PDF, also known as Version of record

\section{Please check the document version of this publication:}

- A submitted manuscript is the version of the article upon submission and before peer-review. There can be important differences between the submitted version and the official published version of record.

People interested in the research are advised to contact the author for the final version of the publication, or visit the DOI to the publisher's website.

- The final author version and the galley proof are versions of the publication after peer review.

- The final published version features the final layout of the paper including the volume, issue and page numbers.

Link to publication

\footnotetext{
General rights rights.

- You may freely distribute the URL identifying the publication in the public portal. please follow below link for the End User Agreement:

www.umlib.nl/taverne-license

Take down policy

If you believe that this document breaches copyright please contact us at:

repository@maastrichtuniversity.nl

providing details and we will investigate your claim.
}

Copyright and moral rights for the publications made accessible in the public portal are retained by the authors and/or other copyright owners and it is a condition of accessing publications that users recognise and abide by the legal requirements associated with these

- Users may download and print one copy of any publication from the public portal for the purpose of private study or research.

- You may not further distribute the material or use it for any profit-making activity or commercial gain

If the publication is distributed under the terms of Article $25 \mathrm{fa}$ of the Dutch Copyright Act, indicated by the "Taverne" license above, 
Time Discounting and the Body Mass Index

\author{
ROA-RM-2005/5E \\ Lex Borghans, Bart H.H. Golsteyn
}

Research Centre for Education and the Labour Market

Faculty of Economics and Business Administration

Maastricht University

Maastricht, July 2005 
ISBN 90-5321-411-9

Sec05.051.doc 


\section{Contents}

Abstract

Acknowledgement

1 Introduction 1

2 The Model 3

3 The data and empirical strategy 6

4 Cross-sectional relationship between time discounting and BMI 14

$5 \quad$ The relationship between time discounting and BMI over time 22

6 Discussion and conclusions $\quad 27$

$\begin{array}{lr}\text { Literature } & 28\end{array}$ 



\begin{abstract}
In many Western countries, the relative weight of people - measured by the Body Mass Index (BMI) - has increased substantially in recent years, leading to an increasing incidence of overweight and related health problems. As with many forms of risky behavior, it is plausible that overweight is related to the individual discount rate. Increases in credit card debts, the rise in gambling and the development of a more hedonic life style, suggest that the average discount rate has increased over time. This increase may have been the cause of the increase in BMI. Applying a large set of indicators for the individual discount rate, this paper analyzes whether changes in time discounting can account for differences in body mass between individuals at a given point in time and whether changes in the average individual discount rate can explain the remarkable increase in BMI experienced in recent years. We find some evidence for a link between time discounting and differences in BMI between people, but this relationship depends strongly on the choice of the proxy for the discount rate. Giving our hypothesis the best chance, we analyze the development of the time discounting proxies that are most strongly related to BMI. We find no evidence for a change of these proxies over time. Our main conclusion therefore is that overweight might be related to the way people discount future health benefits, but the increase in BMI has to be explained by shifts in other parameters that determine the intertemporal decisions regarding the trade-off of current and future health and satisfaction.
\end{abstract}

\title{
Acknowledgement
}

The authors thank Erik de Regt, Inge Sieben, Patricia Smith, Wendy Smits and Bas ter Weel for useful comments, John Komlos for his encouragement to write this study and CenterData for providing the data of the DNB household survey. 



\section{Introduction}

In recent years, many Western countries have experienced a substantial increase in the average body mass of their population. This steady increase has serious consequences for life expectancy and health in general. It therefore raises the question why people take in more calories than recommended at the expense of future health, and why this behavior has changed so much in the past decade. Comparable to many other forms of risky behavior, it is plausible to assume a link between the individual discount rate and overweight. People who trade off current benefits against future costs at a high discount rate, put great weight on current pleasure and comfort obtained through eating, while giving relatively low weight to the potential future health problems related to this behavior. Increases in credit card debts, the rise in gambling and the development of a more hedonic life style, suggest that the average discount rate has increased over time. Along this argument, an increase in the average individual discount rate, could therefore explain the recent increase in the average Body Mass Index (BMI).

The aim of this paper is to investigate (i) whether differences in BMI between people at a certain moment of time are related to the individual discount rate, and (ii) whether a positive trend in time discounting can account for the increase of BMl over time. To analyze this question we use data of a survey among a sample of the Dutch population, for the period 1995-2004. This data set contains information about weight and length, and has a very large set of questions concerning the financial situation and attitude of the respondents. These questions offer ample opportunities for proxies to measure the individual discount rate. In 2004 we added a supplementary questionnaire to this survey with standard psychological questions for measuring the individual discount rate. On the basis of the 2004 data we are able to directly investigate the link between the discount rate and BMI, and to investigate the validity of a wide range of financial questions as proxies for the discount rate. Using the validated proxies we investigate the development of the individual discount rate and its link with BMI over time.

Our main findings are that differences in BMI between people in a specific year in the sample are related to some of our measures of the individual discount rate. Especially measures that are related to difficulties to manage expenditures are correlated with BMI. Comparing different years, however, it turns out that the average individual discount rate did not change from 1995 - 2004. The upward trend in BMl can therefore not be accounted for by an increase in the individual discount rate.

The cross-sectional correlation between the individual discount rate and BMI differs substantially between the sexes and age groups. On the basis of our theoretical model, we hypothesize that alternative possibilities to invest in human capital and to engage in risky behavior which are substitutes and/or complements to overconsumption of food could contribute to the explanation of these differences. Keeping in mind the broad character of human capital, these intervening alternatives could be related to health, but also to education and work. Consequently, the recent increase in BMI can also be related to price changes of these complements and substitutes. 
This paper is related to the recent literature investigating the causes of the remarkable increase in BMI (Popkin and Doak, 1998; Flegal et al., 1998; Mokdad et al., 1999; Philipson, 2001; Komlos and Baur, 2004; Ogden et al., 2004). Technological change has been put forward as an explanation for increasing weights because it has simultaneously lowered the relative price of food and reduced the amount of physical activity required at work and in daily activity (Philipson and Posner, 1999; Lakdawalla and Philipson, 2002; Philipson, 2001). Cutler, Glaeser and Shapiro (2003) argue that the decrease in the price of calories is of the right magnitude to explain the increase in $\mathrm{BMI}$, while the downward trend in physical activity is far too small to account for this development.

The paper is also related to the literature about differences in individual discount rates. On the basis of the human capital theory, which regards healthy behavior as an investment, as introduced by Becker (1964) and further developed by Grossman (1972), variations in health outcomes are often explained by differences in discount rates. Empirically, these relationships are not very robust however. Among others, Fuchs (1982) and Chapman and Coups (1999) find only minor relations between discount rates and health behavior, where the relations are not found for all measures of time preference or for all behaviors. Chapman and Elstein (1995) and Chapman, Nelson and Hier (1999) find only weak correlations between discount rates for money and for health. On the other hand, Bickel, Odum and Madden (1999), Kirby, Petry and Bickel (1999), Madden et al. (1997) and Vuchinich and Simpson (1998) find consistent relations between time preference and addictive behaviors. More in general, the individual discount rate is expected to play a crucial role in educational participation, and behavior in the labor market. Empirical evidence is scarce, however. Fersterer and Winter-Ebmer (2003) show that young people who stay in school longer tend to have a lower discount rate. DellaVigna and Paserman (2004) investigate job search behavior focusing on two opposing effects of time discounting. They find that more impatient workers search less intensively for a job, set a lower reservation wage and exit unemployment later, as predicted by a hyperbolic discounting model. Munasinghe and Sicherman (2000) find that workers with higher measured impatience select jobs with flatter wage profiles. Several other authors point at alleged contradictions with respect to time discounting. Komlos, Smith and Bogin (2004) put forward that while BMI increased, investments in fitness equipment also increased. Ruhm (2000) shows that in economic booms, health outcomes deteriorate, while health improves during recessions. Despite these ambiguous findings, many papers use risky behavior, e.g. smoking, as a proxy for time discounting (e.g. Sykes, Evans and McCrum, 1990; Evans and Montgomery, 1994; Chevalier and Walker, 1999; Munasinghe and Sicherman, 2000; Fersterer and WinterEbmer, 2003). Frederick, Loewenstein and O'Donoghue (2002) give a more extensive overview of these findings.

The literature on changes in the discount rate over time is less extensive. Some evidence seems to suggest that the average discount rate has increased. The National Gambling Impact Study Commission (1999) reports an increase in legal gambling in the U.S. over the past three decades. Blaylock et al. (1999) note that personal savings in America has decreased and that credit card debt has risen. Parker (1999) documents the decline in 
personal savings since 1980, as well as the decline in private savings and the rise in personal consumption as a percentage of GDP.

Blaylock et al. (1999) and Levy (2002) provide theoretical models explaining obesity using individual differences in the discount rate. In a recent paper Komlos, Smith and Bogin (2004) are the first to hypothesize that the trend in obesity could be related to an increase in time preference. They provide evidence from a cross-country comparison of average BMI and saving rates, and time series evidence about these variables for the US, consistent with their hypothesis. However, as they acknowledge, these aggregate variables are probably poor proxies for the discount rate, which ask for more direct data about the discount rate at a micro level to investigate this hypothesis. Cutler and Glaeser (2005) investigate the link between time discounting and obesity by comparing BMI with other forms of risky behavior and conclude that time discounting cannot explain obesity. Allowing for substitutability or complementarity between investments and risky behaviors, we will show that the individual discount rate might have very different impacts on each form of behavior.

The remainder of this paper is organized as follows. Section 2 introduces the model. Section 3 is concerned with the description of the data. Section 4 investigates the cross-sectional relationship between time discounting and BMI. Section 5 analyzes the relationship between time discounting and BMI over time. Section 6 discusses the findings.

\section{The Model}

Theoretically, BMI and the individual discount rate are related because the immediate consequences of calorie intake differ from the future consequences. Excessive food intake leads to immediate pleasure or reduction of distress, while it reduces future health and physical appearance. This is a similar trade-off as in many other investment decisions regarding health, education, etc. In a two-period setting, assume that the utility of an agent in period 1 equals $U_{1}=\gamma_{A} A^{\delta}$ (with $\gamma \mathrm{A}>0$ and $0<\delta<1$ ), and utility in period 2 equals $U_{2}=-A$, in which A represents a certain form of behavior that increases utility in period 1 , but diminishes utility in period 2 . The disutility of $A$ in period 2 is used as unit of measurement. $\delta$ and $\gamma \mathrm{A}$ are parameters regarding the diminishing marginal utility of $A$ and the pleasure one derives of $A$, respectively. The price of $A$ in period $1-$ e.g. the price of food - equals PA. An agent with an individual discount rate $\rho$, who maximizes the discounted utility for both periods, will maximize:

$$
U=U_{1}-P_{A} A+U_{2}=\gamma_{A} A^{\delta}-P_{A} A-\frac{1}{1+\rho} A
$$


The optimal level of A equals:

$$
A=\left(\frac{\delta \gamma_{A}}{P_{A}+\frac{1}{1+\rho}}\right)^{\frac{1}{1-\delta}} .
$$

This expression for A provides potential explanations for why people differ in calorie intake and consequently in BMI. Assuming the technical parameter $\delta$ to be equal for all individuals, differences can be related to PA, $\rho$, or $\gamma \mathrm{A}$. At a certain moment in time, all agents will face the same prices, so cross-sectional variation in this model can only be related to differences in the discount rate and differences in $\gamma \mathrm{A}$, reflecting differences in the relative importance of calorie intake compared to the future consequences of this behavior. Examples of this variation could be simple differences in the preferences for food, but also differences in the health risk of obesity to different people. The function shows that people will gain more weight if $\gamma \mathrm{A}$ increases, if prices decrease, or the discount rate increases. The same expression also provides a framework for understanding shifts over time in the average BMI of the population. Since we are looking at averages, the increasing trend in BMI could be explained by an increase of the average individual discount rate, $\rho$, the average relative pleasure of people in food consumption $\gamma_{A}$, and of course changes in the average price of calorie-rich food. Note that when there are individual differences in the discount rate, such changes can shift the BMI of all people simultaneously, but can also affect high discounters more than low discounters. In the specification that has been chosen here, a change in the price of food would increase the BMI of all agents simultaneously, while a change in the average $\gamma_{A}$, would increase the average BMI by widening the gap between the BMI of high and low discounters.

When the individual discount rate is interpreted as a parameter of the utility function, an increase in BMI does not necessarily imply a fall in welfare. In that situation a fall in prices always implies improved welfare, with people apparently preferring to enjoy high levels of food consumption at the cost of future health problems. Cutler, Glaeser, and Shapiro (2003) argue that with hyperbolic discounting it is possible that lower prices lead to behavior associated with a loss of welfare. A more general interpretation of time discounting in which the discount rate also reflects a lack of power of imagination (see Becker and Mulligan, 1997, and Borghans and Golsteyn, 2005) leads to similar conclusions.

In the setting presented here, the absence of an empirical link between individual discount rates and BMI is almost equivalent to a rejection of the Discounted-Utility Model (Samuelson, 1937; Koopmans, 1960; Lancaster, 1963; Fishburn, 1970). Several authors have put forward arguments against this model. For example, Loewenstein (1992) argues that a utility function with one single parameter to describe intertemporal decisions is too restrictive, and proposes specifications with separate "discount rates" for each individual good. Mulligan (2005) argues that there can be no variation in individual discount rates, because people with discount rates that differ from the market discount rate would be exploited by profit maximizing firms. 
In practice, however, overconsumption of food is not the only temptation in life. In a more general framework alternative possibilities to either invest in future benefits or enjoy life have to be considered simultaneously. Suppose, an agent has to decide about two forms of behavior, $A$ and $B$, which both provide utility in period 1 and disutility in period 2 . Generalizing the utility function in period 1 to $U_{1}=\left(\gamma_{A} A^{v}+\gamma_{B} B^{v}\right)^{\frac{\delta}{v}},(v \leq 1)$ and utility in period 2 to $U_{2}=-A-B$, with prices $\mathrm{PA}$ and $\mathrm{PB}$, leads to the following optimal level of $\mathrm{A}{ }^{1}$

$$
A=\left(\frac{\delta \gamma_{A}^{\delta / v}}{P_{A}+\frac{1}{1+\rho}}\right)^{\frac{1}{1-\delta}}\left(1+\left(\frac{\gamma_{A}}{\gamma_{B}}\right)^{\frac{1}{v-1}}\left(\frac{P_{B}+\frac{1}{1+\rho}}{P_{A}+\frac{1}{1+\rho}}\right)^{\frac{\delta}{v}-1}\right)^{\frac{1}{1-\delta}} .
$$

The first part of this equation is almost identical to (2). The second part, however, reveals an interesting interaction between different forms of intertemporal trade-offs. When $A$ and $B$ are no perfect substitutes (so $v \neq 1$ ), differences between people in parameters with respect to aspect $B$, and changes of the price of $B$ and the averages in the distribution, are also going to affect $A$. The impact of these differences depends on the degree of complementarity of $A$ and $B$. The switching point is when $\delta / v=1$. In practice, there are many applications of two aspects that can be substitutable or complementary. For example, when people need distraction to cope with stress, one could imagine smoking and eating to be substitutes. Also, when someone works long hours to invest in a career, food intake could substitute for what the rest the body is asking for. Empirical studies find negative relations between smoking and various outcomes that may be influenced by high discount rates, e.g. health, educational attainment, earnings levels, use of seatbelts, physical exercise, teeth brushing, and teeth flossing (Hersch and Viscusi, 1990; Hersch, 1996; Levine, Gustafson and Velenchik, 1997; Hersch, 2000; Viscusi and Hersch, 2001). On the other hand, e.g. Gulliver (1995), Burton and Tiffany (1997) and Picone, Sloan and Trogdon (2004) provide evidence for the complementarity of smoking and drinking, while Cawley, Markowitz and Tauras (2003) find that girls with higher BMI are on average more likely to start smoking.

It is very interesting to note that the impact of the interaction between two aspects $A$ and $B$ can be different for different values of the individual discount rate. So when the price of $B$ is very low, and thus investing in low B's is beneficial, it will be especially low discounters who do so. When these aspects are substitutes, this will increase consumption of $A$, reversing the relationship between the discount rate and the form of behavior. An example is again the situation in which people who work hard to make a career, consume more food to keep on going. If the benefits from investing in the career exceed the costs of increased BMI, a low discount rate could in theory be related to high BMI. These extensions show that in a more

1. One could further generalize the model by introducing a CES utility function for the second period. In such a model, the future consequences of one type of behaviour also depend on other forms of behaviour. 
general setting, the link between the individual discount rate and BMI becomes an empirical question, which we try to answer in this paper.

\section{The data and empirical strategy}

Our analyses are based on the DNB household Survey, formerly known as the CentER Savings Survey, collected by CentER (Tilburg, the Netherlands). The data are unique for our purposes, because they contain both questions about body length and weight and questions that seem to be very good proxies for time discounting for 1995-2004. In a supplementary survey in 2004, questions are asked that measure time discounting following the tradition in psychological literature.

The data

The survey is taken in March. The samples are representative for the Dutch population of 16 and older. From 1995, this annual survey contains a large number of questions about financial behavior and attitudes, with almost no change in the questions that are used. We use the data from 1995 - 2004. Table 1 provides information about the sample size per year. In 1995, the sample contained 4,854 people. This decreased to 2,059 respondents in 2004 . In 2000, most of the questions that are relevant for our analyses have only been asked to respondents with a job. This was presumably due to an error in the routing of the questionnaire. Since the distribution of characteristics of the working population differs clearly from the characteristics of the population as a whole, we do not use the data for 2000 in the analyses.

Table 1

Sample size per year, 1995-2004

Sample size

1995

4854

1996

4250

1997

3513

1998

2392

1999

2250

2000

1055

2001

2075

2002

2139

2003

2187

2004

2059

Source: DNB household survey

In October 2004, a supplementary survey has been carried out, targeted at the same respondents as the Basic DNB household Survey of 2004, including two questions that 
measure the individual discount rate, following the tradition in psychology (Rachlin, Raineri and Cross, 1991).

Apart from the anthropometric measures, the questions about financial behavior and attitudes that provide many proxies for the individual discount rate and the two psychological questions, the survey provides information about sex, age, educational attainment, and income.

$B M I$

Using the information on length and weight, we calculated the BMI as weight in kilograms over the square of length in meters. The data on length and weight are self-assessed, and may therefore be subject to some bias. Cawley (2000) shows that women, on average, underreport their weight by $1.5 \%$, where underweight women overreport and overweight women underreport. This under- and overreporting hence reduces the standard deviation of $\mathrm{BMI}$ and plausibly therefore self-assessed BMI data should be interpreted slightly different than true BMI measures. However, since the under- and overreporting is related to BMI levels only, relations between BMl and other variables will not be affected by this bias. In addition, the data contains a small fraction of implausible answers. To reduce the impact of outliers, we leave out 7 cases of 2,059 for those claiming to weigh less than 35 or more than 135 kilograms. The average male respondent in our sample in 1995 is $180.6 \mathrm{~cm}$ tall and weighs 79.7 kilograms. In 2004, these averages increased to $180.8 \mathrm{~cm}$ and $83.4 \mathrm{~kg}$. Consequently, the average male BMI increased from 24.4 in 1995 to 25.5 in 2004 . For females, the average height was stable from $168.3 \mathrm{~cm}$ in 1995 to $168.2 \mathrm{~cm}$ in 2004 while average weight increased from $67.2 \mathrm{~kg}$ to $71.9 \mathrm{~kg}$ in 2004 . Their BMl increased from 23.7 in 1995 to $25.4 \mathrm{in}$ 2004. A person with a BMI below 18.5 is considered undernourished. A BMI between 25 and 29.9 is overweight, while a BMI above 30 is obese. Table 2 shows that in 1995, 5.4 percent of the population was obese. In 2004, the percentage of obese people increased to 12.2 percent. The percentage of overweight people increased from 30.2 to 37.0 percent.

Table 2

BMI levels men and women, 2004

\begin{tabular}{|c|c|c|c|c|c|c|c|}
\hline \multicolumn{2}{|l|}{$\mathrm{BMI}^{*}$} & \multirow{2}{*}{$\begin{array}{r}\text { Men } \\
2.2\end{array}$} & $\begin{array}{c}1995 \\
\text { Women }\end{array}$ & Total & \multicolumn{3}{|c|}{2004} \\
\hline$<18.5$ & Undernourished & & 4.2 & 3.1 & 1.1 & 3.0 & 2.0 \\
\hline $18.5<=\mathrm{BMI}<25$ & Normal & 57.5 & 65.5 & 61.3 & 47.3 & 50.6 & 48.9 \\
\hline $25<=\mathrm{BMI}<30$ & Overweight & 36.0 & 23.6 & 30.2 & 42.1 & 31.1 & 37.0 \\
\hline \multirow[t]{2}{*}{$\mathrm{BMI}>=30$} & Obese & 4.3 & 6.7 & 5.4 & 9.4 & 15.3 & 12.2 \\
\hline & Total & 100.0 & 100.0 & 100.0 & 100.0 & 100.0 & 100.0 \\
\hline
\end{tabular}

${ }^{*} \mathrm{BMI}$ is defined as weight in $\mathrm{kg}$ divided by length in meters. 
Figure 1 gives the development of BMI in the population between 1995 and 2004. To facilitate visual comparison of the size of the developments in the graphs, the vertical axes in all graphs are scaled from the average value in the population in all years minus 0.5 standard deviation in this variable, to the same average plus 0.5 standard deviation. The figure clearly shows the large increase in BMI over this period, and shows that women experience a larger increase than men. Figure 2 provides more detailed information for women, breaking down the development of BMI over time by age group. The largest increase in BMI has taken place among the women below 40. The gaps in average BMI between the age groups diminished considerably. Figure 3 breaks down the development in BMI for men by age group. For men the increase has been similar in the three age groups, keeping the gap between men under 40 and the older two age groups intact.

Figure 1

The development of BMI, 1995-2004

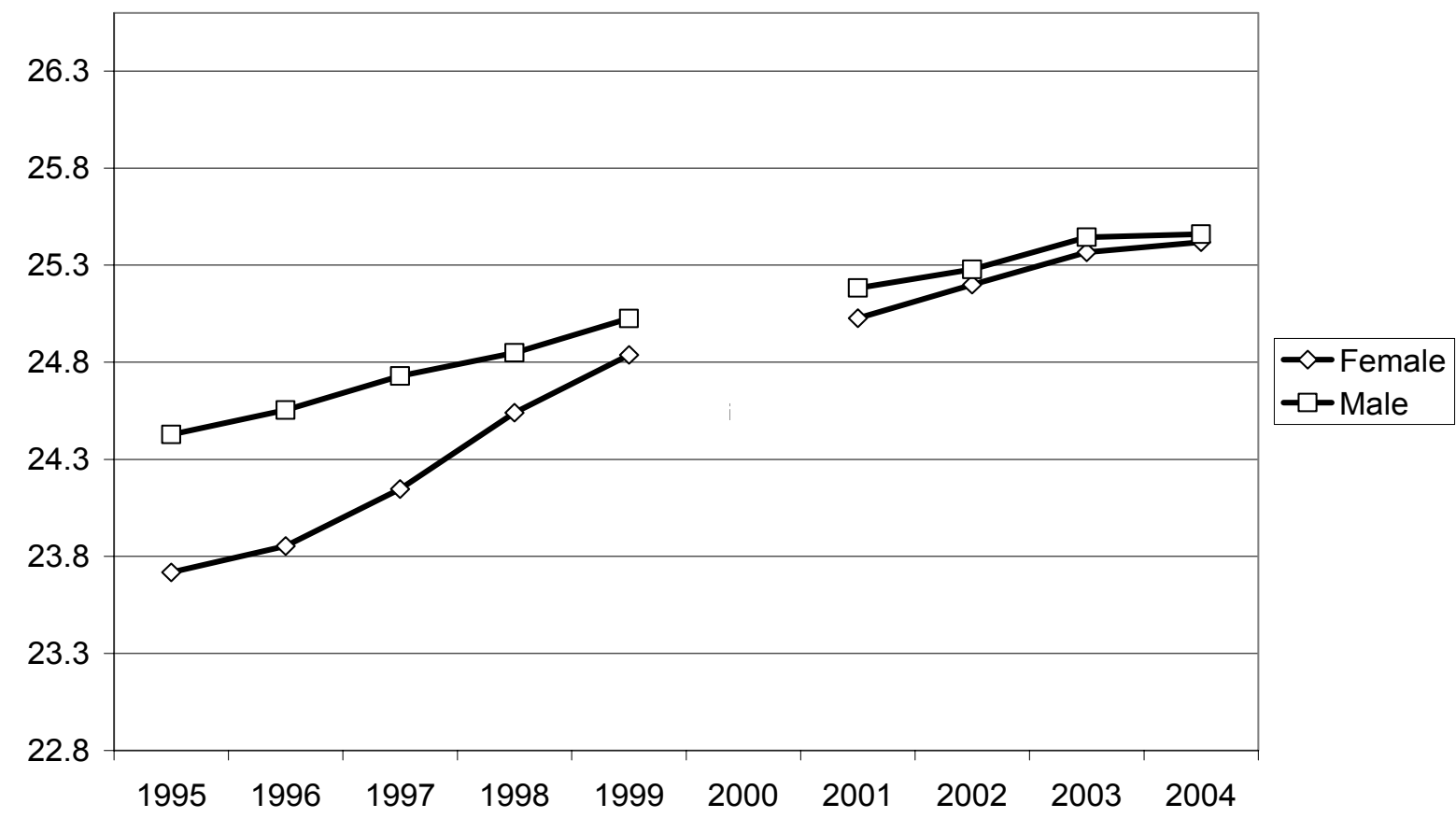

Source: DNB household survey 1995-1999, 2001-2004

Note: $\quad$ The scale of the vertical axis is determined by the mean total score over the years on BMI of men and women together \pm 0.5 times its standard deviation.

\section{Empirical strategy}

In the supplementary survey of 2004 , we were able to include a few questions that aim at measuring the discount rate. Our empirical strategy is, first, to investigate the validity of these psychological discount questions. Second, we compare these measures of the discount rate with a list of potential proxies for the individual discount rate, which are available in the regular survey. Third, we investigate for 2004 the relationship between these proxies and BMI. Fourth, we select the proxies that are most successful in explaining BMI, check the robustness of these results and investigate whether this relationship between a proxy for time discounting and BMI can explain the rise in obesity that is observed in the past decade. 
Figure 2

The development of BMI for females for three age groups, 1995-2004

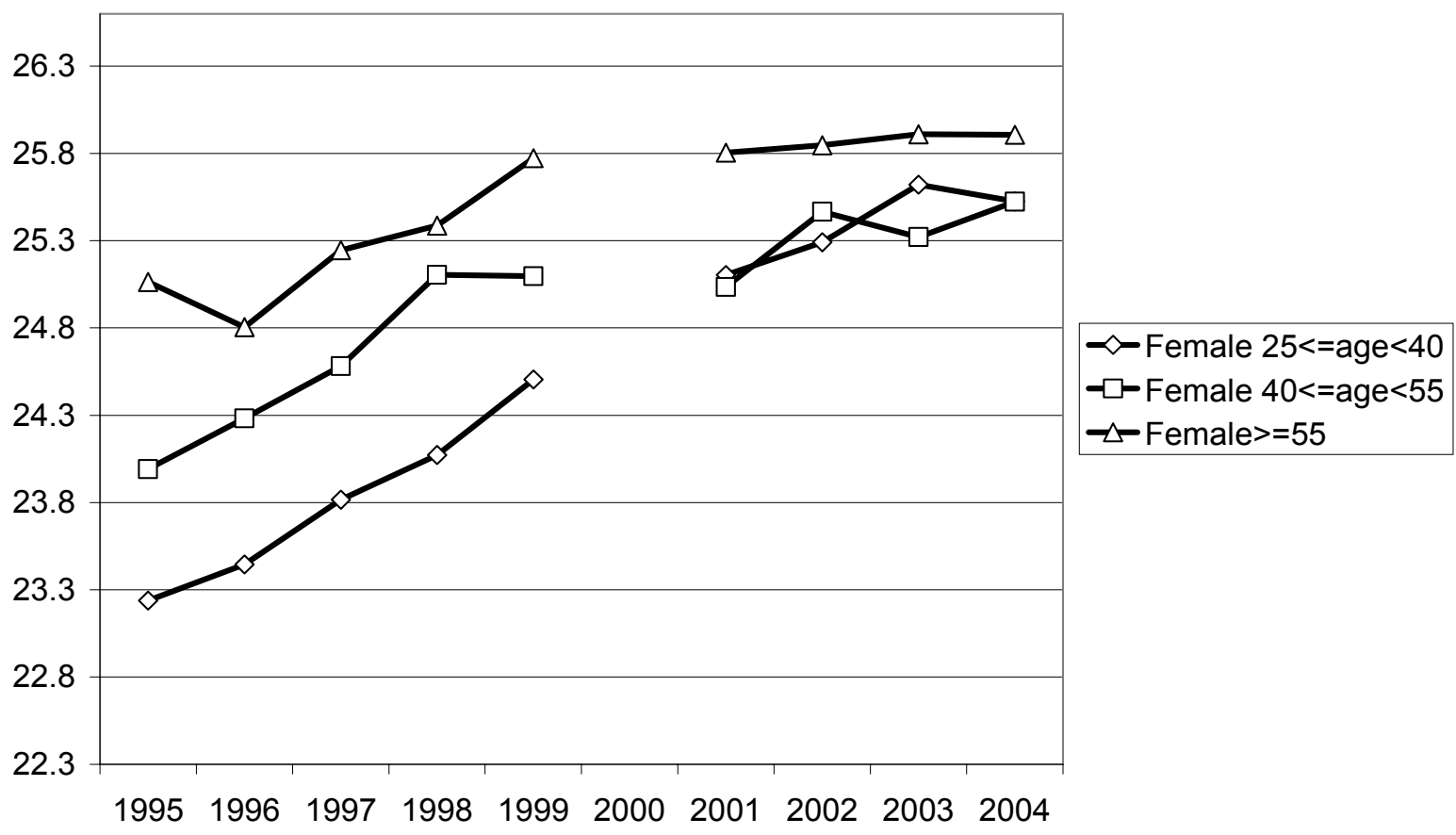

Source: DNB household survey 1995-1999, 2001-2004

Note: $\quad$ The scale of the vertical axis is determined by the mean total score over the years on BMI of women of all age groups together \pm 0.5 times its standard deviation.

Figure 3

The development of BMI for men for three age groups, 1995-2004

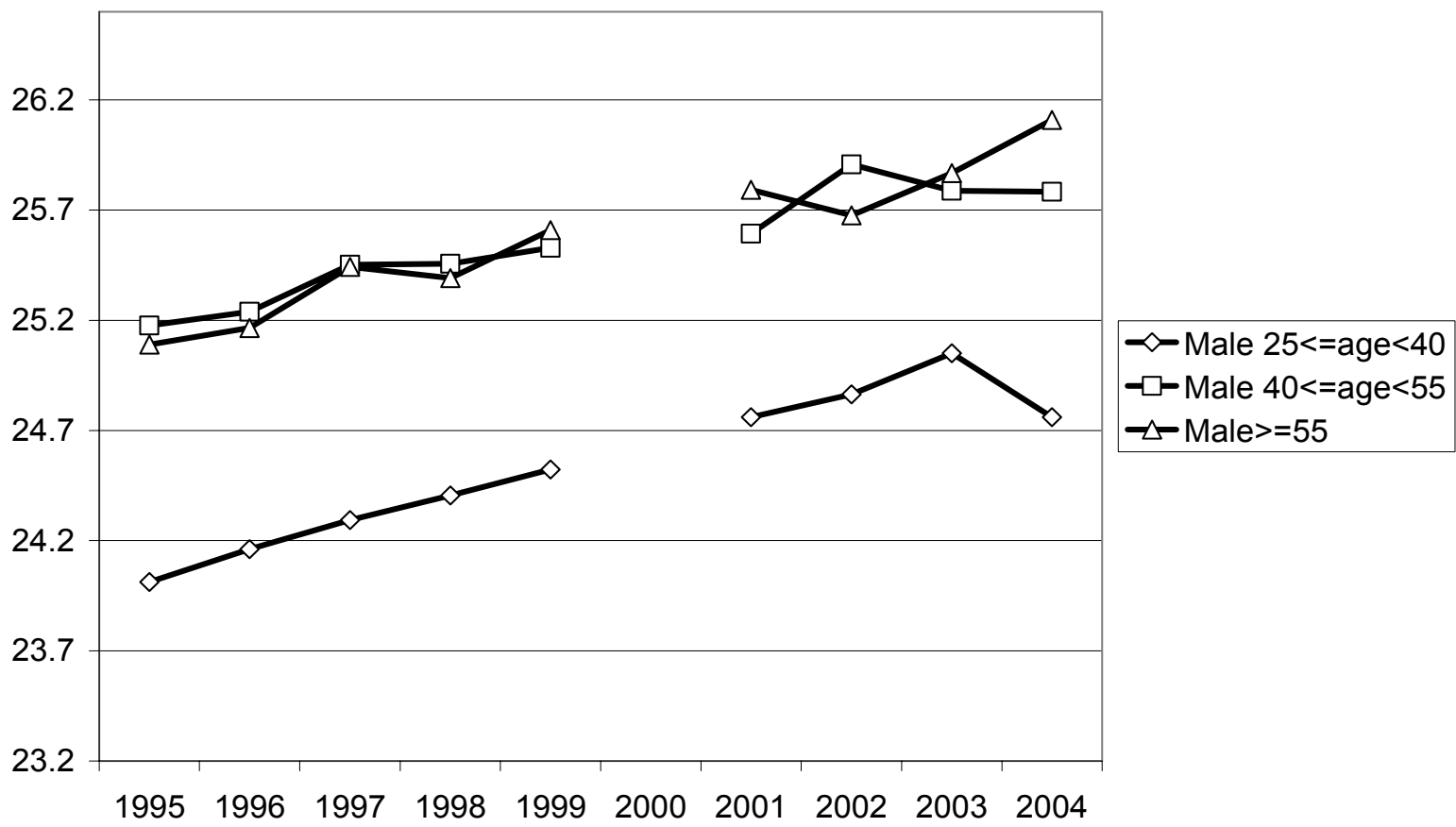

Source: DNB household survey 1995-1999, 2001-2004

Note: $\quad$ The scale of the vertical axis is determined by the mean total score over the years on BMI of women of all age groups together \pm 0.5 times its standard deviation. 
Following the psychological tradition (Rachlin, Raineri and Cross, 1991) we included a battery of six questions, like:

"Please indicate, which alternative you would choose.

150 euro now

270 euro a year from now"

Varying the amount of money in alternative 1 and 2, and the timing of the first and second periods, makes it possible to vary an implicit discount rate and to determine the individual discount rate. Several papers show that the psychological measures to determine the discount rate are rather sensitive to the wording of the question, and to anchoring effects, i.e. imputed discount rates tend to be biased in the direction of the discount rate that equates the first pair of options to which the responds are exposed (Green et al, 1998). We checked the sensitivity of the answers to the level of the awarded money. For a random group of $50 \%$ of the respondents all questions have been asked using amounts that are a factor 10 larger (so "500 euro now" and "700 euro a year from now"). As found in several other papers (see e.g. Thaler, 1985), although the implicit discount rates are the same, the level of the results turns out to depend on the exact question. People who are asked the set with the low money values score significantly higher on the discount rate $(t=6.699)$. Verifying the correlation with a large set of other variables, however, we find no significant differences, which suggests that apart from this level effect, different wordings reflect similar differences between people in their trade-off between the present and the future. In all regressions, we include a dummy variable that equals 1 if the low amounts are asked, and 0 if the high amounts are asked, to control for the specific wordings of the question.

Table 3

Percentages of the respondents choosing the option that gives them gratification sooner with the high and low monetary questions

Questions*

\% Respondents choosing gratification sooner Implicit discount Low amounts High amounts rates

$\begin{array}{lrll}€ 50 \text { now or } € 70 \text { in } 1 \text { year } & 40 & 60.6 & 47.8 \\ € 100 \text { in } 1 \text { year or } € 150 \text { in } 4 \text { years } & 11 & 79.6 & 70.2 \\ € 100 \text { now or } € 100 \text { in } 1 \text { year } & 0 & 95.7 & 96.0 \\ € 50 \text { in 1 year or } € 90 \text { in 2 years } & 80 & 45.3 & 33.1 \\ € 50 \text { now or } € 300 \text { in } 4 \text { years } & 57 & 25.2 & 19.7 \\ € 100 \text { in one year or } € 125 \text { in } 2 \text { years } & 25 & 80.9 & 73.8\end{array}$

Source: DNB household survey, supplementary survey 2004

Note: $\quad$ A randomly selected group of the respondents were asked questions with the same implicit discount rates but higher amounts, i.c. all monetary values in the questions were multiplied by 10 . 
Table 3 provides information about the answers of the respondents on these discount rate questions. For the question mentioned above as an example, which has an implicit breakeven discount rate of $40 \%$, approximately $50 \%$ of the respondents prefer the money now, while $50 \%$ prefer to wait. As usually found, this median individual discount rate is much higher than typical interest rates at a bank. This may in part be due to the wording of the question and anchoring effects, but also reveals that many people tend to put high weight on immediate gratification compared to their future well-being. We use the number of answers in which a respondent prefers to get the money early as a measure for the discount rate.

As an alternative to the standard battery with monetary choices, some authors apply the idea to specific cases instead (see e.g. Frederick, 2005). To investigate the validity of this measure of the individual discount rate, we asked the following additional question following their methodology:

"Suppose you win a 10-day holiday trip to an interesting destination. To spread participation, you are asked if you can delay your trip by three years in exchange for a longer vacation. How many days should you be offered in addition to accept the offer in 3 years' time?"

Answers varied from 0 to 365 days, with a mean of 13.8 days and a standard deviation of 33.2. This corresponds to a discount rate of $24.6 \% .97 .7 \%$ of the observations are in the 0 50 days interval. We truncate our measure at 50 days before calculating the implicit annual discount rate $\left(\left(\frac{\text { days }+10}{10}\right)^{1 / 3}-1\right)$ measure and the discount rate based on the monetary questions (t-value $=5.141$ ).

\section{Proxies for the discount rate}

The basic questionnaire includes a wide variety of questions that are clearly related to the concept of an individual discount rate. We selected 25 questions which seemed to be most appropriate from a theoretical point of view. Table 4 contains the wordings of all these questions. The first three questions are related to the management of income and the question whether the respondent spent more money than he received in the past 12 months. The next group of seven questions concerns statements about saving behavior. In the six questions named SAVE1 to SAVE6 the respondent is asked to indicate to what extent he agrees with the statements on a 7-point scale. RISK asks how risky the investments of the respondent have been. These seven questions seem to be more related to risk aversion than to time discounting, but since risk aversion is known to be related to time discounting (e.g. Gafni and Torrance, 1984) we included them in our set. The next 11 questions (named FUTURE01 to FUTURE11) are again statements about the attitude referring to the trade-off between the present and the future. Based on the wordings of the statements one expects these 
questions to be very good reflections of the individual discount rate. ${ }^{2}$ The questions SPEND and PLAN ask whether the respondent tends to spend income immediately and whether it is difficult for him to plan expenditures. The survey monitors in great detail all different accounts, savings, and loans. ASSETS is the total value of the accounts and different kinds of savings, while LIABILITIES reflects the aggregate value of loans and credits, excluding the mortgage on the first house. We apply these two financial summary statistics in euros and as a ratio to yearly net income.

Table 4

Questions that are used as proxies for the individual discount rate

$\begin{array}{lll}\text { Name } & \text { Question } & \text { Answers }\end{array}$

MANAGE

EXPENDITURES

HOWMUCH

SAVE1

SAVE2

SAVE3

SAVE4

SAVE5

SAVE6

RISK

FUTURE01
How well can you manage on the total income of your household?

Over the past 12 months, would you say the expenditures of your household were higher than the income of the household, about equal to the income of the household, or lower than the income of the household?

About how much money has your household put aside IN THE PAST 12 MONTHS? If you really don't know, type 0 (zero)

I think it is more important to have safe investments and guaranteed returns, than to take a risk to have a chance to get the highest possible returns

I would never consider investments in shares because I find this too risky

If I think an investment will be profitable, I am prepared to borrow money to make this investment

I want to be certain that my investments are safe

I get more and more convinced that I should take greater financial risks to improve my

financial position

I am prepared to take the risk to lose money, when there is also a chance to gain money

What would you say was the risk factor that you have taken with investments over the past few years? If

you haven't made any investments, select answer 6

I think about how things can change in the future, and try to influence those things in my everyday life
1 very hard, 2 hard, 3 neither hard nor easy, 4 easy, 5 very easy

1 the expenditures were higher than the income, 2 the expenditures were about equal to the income, 3 the expenditures were lower than the income

1 less than Dfl. 3,000, 2 $3,000-10,000,310,000$ 25,000, 4 25,000 - 40,000, $540,000-75,000,6$ $75,000-150,000,7$ 150,000 or more 1 totally disagree , .., 7 totally agree

1 totally disagree , .., 7 totally agree

1 totally disagree , .., 7

totally agree

1 totally disagree , .., 7

totally agree

1 totally disagree , .., 7

totally agree

1 totally disagree , .., 7 totally agree

1 I have taken no risk at all, 2 I have taken small risks every now and then , 3 I have taken some risks, 4 I have sometimes taken great risks, $5 \mathrm{I}$ have often taken great, $6^{*}$ not applicable, $0^{*}$ don't know

1 totally disagree , ..., 7

totally agree

2. Several proxies for time discounting could be combined to reduce measurement error. We prefer the analyses of the separate proxies since for most of them, the correlation with the psychological measure of the discount rate is sufficiently large, while furthermore this approach reveals the sensitivity of the results to the specific proxy used. 
Table 4 (continued)

Questions that are used as proxies for the individual discount rate

$\begin{array}{lll}\text { Name } & \text { Question } & \text { Answers }\end{array}$

FUTURE02

FUTURE03

FUTURE04

FUTURE05

FUTURE06

FUTURE07

FUTURE08

FUTURE09

FUTURE10

FUTURE11

SPEND

PLAN

ASSETS

LIABILITIES
I often work on things that will only pay off in a couple of years

I am only concerned about the present, because I trust that things will work themselves out in the future

With everything I do, I am only concerned about the immediate consequences (say a period of a couple of days or weeks)

Whether something is convenient for me or not, to a large extent determines the decisions that I take or

the actions that I undertake

I am ready to sacrifice my well-being in the present to achieve certain results in the future

I think it is important to take warnings about negative consequences of my acts seriously, even if these

negative consequences would only occur in the distant future

I think it is more important to work on things that have important consequences in the future, than to

work on things that have immediate but less important consequences

In general, I ignore warnings about future problems because

I think these problems will be solved

before they get critical

I think there is no need to sacrifice things now for problems that lie in the future, because it will always

be possible to solve these future problems later

I only respond to urgent problems, trusting that problems that come up later can be solved in a later

stage

Some people spend all their income immediately. Others save some money in order to have something

to fall back on. Please indicate what you do with money that is left over after having paid for food, rent,

and other necessities. Are you the sort of person that likes to spend his/her money immediately, or are

you the sort of person that tries to save as much as possible, or are you somewhere in between those two

extremes? If you really don't know, type 0 (zero)

Many people find it difficult to plan or control their expenditures. Do you find it difficult to control

your expenditures? If you really don't know, type 0 (zero)

Aggregate variable including assets in: Checking accounts, Employer-sponsored savings plans, Savings arrangements, linked to a bank account, Deposit books, Savings certificates, Single-premium annuity insurance policies, Savings or endowment insurance policies, Growth funds, Mutual funds and/or mutual fund accounts, Bonds and/or mortgage bonds, Stocks and shares.

Aggregate variable including liabilities in: Private loans, Extended lines of credit, Outstanding debts on hire-purchase contracts, debts based on payment by installment and/or equity based loans, Outstanding debts with mail-order firms, shops or other sorts of retail business, Loans from family or friends, Study loans.
1 totally disagree $, \ldots, 7$ totally agree

1 totally disagree , .., 7 totally agree

1 totally disagree , .., 7 totally agree

1 totally disagree , .., 7 totally agree

1 totally disagree $, \ldots, 7$ totally agree

1 totally disagree , .., 7 totally agree

1 totally disagree , .., 7 totally agree

1 totally disagree , .., 7 totally agree

1 totally disagree , .., 7 totally agree

1 totally disagree , .., 7 totally agree

1 I like to spend all my money immediately, ..., 7 I want to save as much as possible, $0^{*}$ I don't know

1 no, very easy, ..., 7 yeas, very difficult, $0^{*}$ I don't know amount in $€$ and

fraction of net income per year

amount in $€$

and

fraction of net income per year

Note: Answers marked with *, have been coded as missing values in the analyses. 


$\begin{array}{llr}\text { MANAGE } & 3.495 & 0.854 \\ \text { EXPENDITURES } & 2.188 & 0.735 \\ \text { HOWMUCH } & 2.233 & 0.953 \\ \text { SAVE1 } & 5.173 & 1.690 \\ \text { SAVE2 } & 4.473 & 2.054 \\ \text { SAVE3 } & 2.234 & 1.539 \\ \text { SAVE4 } & 5.469 & 1.351 \\ \text { SAVE5 } & 2.738 & 1.622 \\ \text { SAVE6 } & 2.610 & 1.529 \\ \text { RISK } & 4.162 & 1.467 \\ \text { FUTURE01 } & 3.590 & 1.533 \\ \text { FUTURE02 } & 3.657 & 1.525 \\ \text { FUTURE03 } & 3.721 & 1.594 \\ \text { FUTURE04 } & 4.519 & 1.353 \\ \text { FUTURE05 } & 3.410 & 1.459 \\ \text { FUTURE06 } & 5.160 & 1.255 \\ \text { FUTURE07 } & 4.241 & 1.333 \\ \text { FUTURE08 } & 3.255 & 1.375 \\ \text { FUTURE09 } & 3.867 & 1.420 \\ \text { FUTURE10 } & 3.719 & 1.469 \\ \text { FUTURE11 } & 4.070 & 1.959 \\ \text { SPEND } & 4.966 & 1.245 \\ \text { PLAN } & 2.933 & 1.568 \\ \text { ASSETS/100,000 } & 0.272 & 0.676 \\ \text { LIABILITIES/100,000 } & 0.260 \\ \text { ASSETS/(net income per year) } & 0.030 & 210.097 \\ \text { LIABILITIES/(net income per year) } & 9.407 & 2.201 \\ & 0.258 & \end{array}$

Source: DNB household survey 2004

Table 5 provides some statistics for these proxy variables for the individual discount rate.

\section{Cross-sectional relationship between time discounting and BMI}

To investigate the link between time discounting and BMI, we analyze whether the proxies based on financial information and attitudes are indeed related to the individual discount rate. Using the data for 2004 , we regress BMI on each of these proxies, saturating the model for age and sex (i.e. we included a full set of sex-age dummies, to ensure that all age and sex differentials are excluded from the analyses). The first column of Table 6 provides the estimates of the parameters for the proxy of the discount rate. With a few exceptions, we find a strong significant relationship between the proxies and the psychological measure of the discount rate. Very interesting exceptions are the assets and liabilities of the respondent. ASSETS is significantly related to the psychological measure of the discount rate, but when 
Table 6

Relationship between the discount rate and BMI as dependent variables and proxies for the discount rate as independent variables

$$
\begin{array}{llll}
\text { DR }^{*} & \text { BMI } & & \\
\text { Coef } & \text { St.Dev. Sign } & \text { Coef } & \text { St.Dev. Sign }
\end{array}
$$

$\begin{array}{lrrlrlll}\text { DR } & & & & 0,096 & 0,060 & \\ \text { MANAGE } & -0.331 & 0.047 & * * * & -0.785 & 0.116 & * * * \\ \text { EXPENDITURES } & -0.250 & 0.055 & * * * & -0.597 & 0.134 & * * * \\ \text { HOWMUCH } & -0.272 & 0.053 & * * * & -0.474 & 0.126 & * * * \\ \text { SAVE1 } & -0.087 & 0.025 & * * * & -0.041 & 0.061 & \\ \text { SAVE2 } & 0.073 & 0.021 & * * * & 0.159 & 0.051 & * * * \\ \text { SAVE3 } & -0.016 & 0.028 & & 0.091 & 0.069 & \\ \text { SAVE4 } & -0.079 & 0.032 & * * & -0.107 & 0.076 & \\ \text { SAVE5 } & -0.013 & 0.026 & & 0.015 & 0.063 & \\ \text { SAVE6 } & -0.055 & 0.028 & * & -0.053 & 0.069 & \\ \text { RISK } & 0.095 & 0.022 & * * * & 0.046 & 0.053 & \\ \text { FUTURE01 } & -0.115 & 0.028 & * * * & -0.048 & 0.069 & \\ \text { FUTURE02 } & -0.151 & 0.027 & * * * & 0.018 & 0.067 & \\ \text { FUTURE03 } & 0.183 & 0.026 & * * * & 0.207 & 0.065 & * * * \\ \text { FUTURE04 } & 0.080 & 0.025 & * * * & 0.123 & 0.063 & * \\ \text { FUTURE05 } & -0.012 & 0.030 & & 0.093 & 0.074 & \\ \text { FUTURE06 } & -0.084 & 0.029 & * * * & -0.064 & 0.071 & \\ \text { FUTURE07 } & -0.124 & 0.033 & * * * & -0.014 & 0.080 & \\ \text { FUTURE08 } & -0.155 & 0.031 & * * * & -0.148 & 0.076 & * \\ \text { FUTURE09 } & 0.089 & 0.030 & * * * & 0.088 & 0.072 & \\ \text { FUTURE10 } & 0.077 & 0.029 & * * * & -0.045 & 0.070 & \\ \text { FUTURE11 } & 0.122 & 0.027 & * * * & 0.073 & 0.068 & \\ \text { SPEND } & -0.153 & 0.033 & * * * & -0.116 & 0.081 & \\ \text { PLAN } & 0.103 & 0.026 & * * * & 0.489 & 0.063 & * * * \\ \text { ASSETS/100,000 } & -0.395 & 0.062 & * * * & -0.280 & 0.146 & * \\ \text { LIABILITIES/100,000 } & -0.137 & 0.143 & & 0.358 & 0.343 & \\ \text { ASSETS/(net income per } & 0.148 & 0.200 & & -0.026 & 0.465 & \\ \text { year*1000) } & & & & & & \\ \text { LIABILITIES/(net income per } & 23.666 & 19.985 & & 47.082 & 44.459 & \\ \text { year*1000) } & & & & & & \end{array}$

Source: DNB household survey 2004 and supplementary survey 2004

Notes: The table contains the estimated coefficients for the proxies of the discount rate in an OLS regression with DR and BMI as regressand, further including a full set of unreported dummies for all combinations of age and sex.

The indicated significance levels are $1 \%\left({ }^{* * *}\right), 5 \%\left({ }^{* *}\right)$ and $10 \%\left({ }^{*}\right)$.

* To control for the level differences in the discount rate, a dummy variable was included in all regressions with DR as dependent or independent variable, being 1 if the respondents answered the questions with low money amounts and 0 if the respondents answered questions in which the money amounts were multiplied by 10 .

the assets for the income of the respondent is adjusted, this relationship disappears. These financial summaries are therefore no adequate proxies for the discount rate. For research purposes, this is unfortunate since such financial summary statistics are available for longer time periods in many countries. SAVE2 and SAVE6 have signs opposite to those expected. 
Apart from these figures, most proxies however seem to be adequate measures for the discount rate. The next step in our analyses is to investigate whether these proxies of time discounting are related to BMI. For some proxies there is a significant relationship between time discounting and BMI, while for others this link is absent. Especially several questions related to the ability to manage expenditures have a significant parameter. It can be concluded therefore that there may be a relationship between time discounting and BMI, but this link is very sensitive to the exact variable that is chosen to proxy time discounting. An interesting topic for future research is to analyze the similarities in the proxies that are related to $\mathrm{BMI}$ in comparison with those that are not.

Table 7a-7d provide similar estimates for the relationship between time discounting and BMI, breaking the sample in different sex and age groups. In general, the link between time discounting and $\mathrm{BMI}$ is stronger for women than for men. For women, we find the strongest relationship in the age group 25-40. For men in this age group, however, the correlation between time discounting and BMI is almost absent. PLAN and MANAGE are the variables that have the highest level of significance in the overall relationship with $\mathrm{BMI}$, and remain significant in most regressions for subgroups. Only for the age group 55+, MANAGE is not significantly related to BMI for men and women, while PLAN has no significant relationship with BMI for men in this age group. To give the hypothesis that the increase in BMI is related to a change in the average discount rate over time the best chance, we will use these two proxies for our further analyses. 


\begin{tabular}{|c|c|c|c|c|c|c|c|c|c|}
\hline & \multicolumn{3}{|c|}{ ALL } & \multicolumn{3}{|c|}{ WOMEN } & \multicolumn{3}{|c|}{ MEN } \\
\hline & BMI & & & BMI & & & BMI & & \\
\hline & Coef & St.Dev. & Sign & Coef & St.Dev. & Sign & Coef & St.Dev. & Sign \\
\hline $\mathrm{DR}^{*}$ & 0.096 & 0.060 & & 0.066 & 0.106 & & 0.123 & 0.066 & * \\
\hline MANAGE & -0.785 & 0.116 & $* * *$ & -0.953 & 0.189 & $* * *$ & -0.612 & 0.137 & $* * *$ \\
\hline EXPENDITURES & -0.597 & 0.134 & $* * *$ & -0.957 & 0.231 & $* * *$ & -0.302 & 0.152 & $* *$ \\
\hline HOWMUCH & -0.474 & 0.126 & $* * *$ & -0.798 & 0.199 & $* * *$ & -0.122 & 0.155 & \\
\hline SAVE1 & -0.152 & 0.078 & * & -0.097 & 0.106 & & 0.006 & 0.068 & \\
\hline SAVE2 & 0.150 & 0.069 & $* *$ & 0.215 & 0.093 & $* *$ & 0.120 & 0.055 & ** \\
\hline SAVE3 & 0.100 & 0.074 & & -0.024 & 0.138 & & 0.151 & 0.070 & $* *$ \\
\hline SAVE4 & -0.207 & 0.102 & ** & -0.082 & 0.130 & & -0.130 & 0.088 & \\
\hline SAVE5 & -0.001 & 0.068 & & 0.027 & 0.117 & & 0.006 & 0.068 & \\
\hline SAVE6 & -0.053 & 0.069 & & -0.091 & 0.131 & & -0.026 & 0.074 & \\
\hline RISK & 0.046 & 0.053 & & 0.097 & 0.092 & & 0.003 & 0.059 & \\
\hline FUTURE01 & -0.019 & 0.075 & & -0.106 & 0.117 & & 0.006 & 0.078 & \\
\hline FUTURE02 & 0.024 & 0.072 & & 0.072 & 0.117 & & -0.026 & 0.075 & \\
\hline FUTURE03 & 0.197 & 0.071 & $* * *$ & 0.196 & 0.116 & * & 0.213 & 0.072 & $* * *$ \\
\hline FUTURE04 & 0.107 & 0.067 & & 0.080 & 0.112 & & 0.151 & 0.069 & $* *$ \\
\hline FUTURE05 & 0.082 & 0.083 & & 0.086 & 0.128 & & 0.100 & 0.084 & \\
\hline FUTURE06 & -0.017 & 0.076 & & -0.173 & 0.123 & & 0.032 & 0.080 & \\
\hline FUTURE07 & -0.058 & 0.100 & & 0.108 & 0.138 & & -0.116 & 0.090 & \\
\hline FUTURE08 & -0.089 & 0.084 & & -0.205 & 0.134 & & -0.103 & 0.084 & \\
\hline FUTURE09 & 0.091 & 0.076 & & 0.008 & 0.126 & & 0.153 & 0.081 & * \\
\hline FUTURE10 & -0.065 & 0.075 & & -0.130 & 0.123 & & 0.021 & 0.078 & \\
\hline FUTURE11 & 0.107 & 0.073 & & 0.030 & 0.120 & & 0.107 & 0.075 & \\
\hline SPEND & -0.215 & 0.091 & $* *$ & -0.125 & 0.141 & & -0.117 & 0.091 & \\
\hline PLAN & 0.480 & 0.066 & $* * *$ & 0.628 & 0.109 & $* * *$ & 0.378 & 0.071 & $* * *$ \\
\hline ASSETS $/ 100,000$ & -0.280 & 0.146 & * & -0.370 & 0.333 & & -0.249 & 0.139 & * \\
\hline LIABILITIES/100,000 & 0.358 & 0.343 & & 3.143 & 1.795 & * & 0.211 & 0.289 & \\
\hline $\begin{array}{l}\text { ASSETS/(net income } \\
\text { per year*1000) }\end{array}$ & -0.026 & 0.465 & & 2.970 & 13.775 & & -0.031 & 0.379 & \\
\hline $\begin{array}{l}\text { LIABILITIES/(net } \\
\text { income per } \\
\text { year*1000) }\end{array}$ & 47.082 & 44.459 & & 38.446 & 58.484 & & 75.599 & 78.498 & \\
\hline
\end{tabular}

Source: DNB household survey 2004 and supplementary survey 2004

Notes: The table contains the estimated coefficients for the proxies of the discount rate in an OLS regression with BMI of all respondents and females and males separately as regressand, further including a full set of unreported dummies for all combinations of age and sex.

The indicated significance levels are $1 \%\left({ }^{* * *}\right), 5 \%\left({ }^{* *}\right)$ and $10 \%\left({ }^{*}\right)$.

* To control for the level differences in the discount rate, a dummy variable was included in all regressions with DR as regressor, being 1 if the respondents answered the questions with low money amounts and 0 if the respondents answered questions in which the money amounts were multiplied by 10 . 
Table $7 b$

Relationship between BMI and proxies for the discount rate for age groups $25-40$ by sex

\begin{tabular}{|c|c|c|c|c|c|c|c|c|c|}
\hline & & ALL & & & OMEN & & & MEN & \\
\hline & $\mathrm{BMI}$ & & & BMI & & & BMI & & \\
\hline & Coef & St.Dev. & Sign & Coef & St.Dev. & Sign & Coef & St.Dev. & Sign \\
\hline $\mathrm{DR}^{*}$ & 0.202 & 0.151 & & 0.256 & 0.245 & & 0.126 & 0.168 & \\
\hline MANAGE & -1.030 & 0.235 & $* * *$ & -1.412 & 0.366 & $* * *$ & -0.547 & 0.275 & $* *$ \\
\hline EXPENDITURES & -1.028 & 0.269 & $* * *$ & -1.580 & 0.432 & $* * *$ & -0.420 & 0.303 & \\
\hline HOWMUCH & -0.638 & 0.257 & $* *$ & -1.215 & 0.365 & $* * *$ & 0.307 & 0.339 & \\
\hline SAVE1 & 0.151 & 0.137 & & 0.285 & 0.233 & & 0.031 & 0.148 & \\
\hline SAVE2 & 0.384 & 0.111 & $* * *$ & 0.599 & 0.179 & $* * *$ & 0.157 & 0.125 & \\
\hline SAVE3 & -0.101 & 0.140 & & -0.261 & 0.238 & & 0.043 & 0.150 & \\
\hline SAVE4 & 0.102 & 0.162 & & 0.423 & 0.261 & & -0.240 & 0.180 & \\
\hline SAVE5 & -0.220 & 0.129 & * & -0.229 & 0.211 & & -0.212 & 0.144 & \\
\hline SAVE6 & -0.347 & 0.140 & ** & -0.484 & 0.233 & ** & -0.215 & 0.153 & \\
\hline RISK & 0.051 & 0.113 & & 0.121 & 0.181 & & -0.027 & 0.127 & \\
\hline FUTURE01 & 0.068 & 0.154 & & 0.064 & 0.250 & & 0.072 & 0.171 & \\
\hline FUTURE02 & -0.054 & 0.150 & & 0.114 & 0.244 & & -0.238 & 0.165 & \\
\hline FUTURE03 & 0.208 & 0.147 & & 0.189 & 0.241 & & 0.227 & 0.161 & \\
\hline FUTURE04 & 0.158 & 0.138 & & 0.196 & 0.227 & & 0.118 & 0.152 & \\
\hline FUTURE05 & 0.234 & 0.170 & & 0.434 & 0.277 & & 0.018 & 0.189 & \\
\hline FUTURE06 & -0.001 & 0.161 & & -0.033 & 0.262 & & 0.035 & 0.179 & \\
\hline FUTURE07 & 0.172 & 0.178 & & 0.205 & 0.287 & & 0.135 & 0.200 & \\
\hline FUTURE08 & -0.073 & 0.178 & & -0.282 & 0.291 & & 0.149 & 0.195 & \\
\hline FUTURE09 & 0.201 & 0.170 & & 0.177 & 0.281 & & 0.225 & 0.185 & \\
\hline FUTURE10 & -0.079 & 0.163 & & -0.057 & 0.260 & & -0.105 & 0.186 & \\
\hline FUTURE11 & 0.160 & 0.157 & & 0.365 & 0.256 & & -0.061 & 0.173 & \\
\hline SPEND & -0.471 & 0.155 & $* * *$ & -0.570 & 0.253 & $* *$ & -0.365 & 0.171 & ** \\
\hline PLAN & 0.663 & 0.135 & $* * *$ & 1.016 & 0.221 & $* * *$ & 0.320 & 0.147 & $* *$ \\
\hline ASSETS/100,000 & -2.434 & 1.006 & $* *$ & -4.127 & 1.718 & $* *$ & -0.898 & 1.030 & \\
\hline LIABILITIES/100,000 & 4.346 & 1.807 & ** & 5.888 & 3.150 & * & 3.027 & 1.815 & * \\
\hline $\begin{array}{l}\text { ASSETS/(net income } \\
\text { per year*1000) }\end{array}$ & -219.363 & 164.132 & & -267.539 & 216.427 & & -23.011 & 275.838 & \\
\hline $\begin{array}{l}\text { LIABILITIES/(net } \\
\text { income per year*1000) }\end{array}$ & 290.682 & 208.679 & & 250.224 & 265.822 & & 547.332 & 419.747 & \\
\hline
\end{tabular}

Source: DNB household survey 2004 and supplementary survey 2004

Notes: The table contains the estimated coefficients for the proxies of the discount rate in an OLS regression with BMI of all respondents between the age of 25 and 40 and females and males separately as regressand, further including a full set of unreported dummies for all combinations of age and sex.

The indicated significance levels are $1 \%\left({ }^{* * *}\right), 5 \%\left({ }^{* *}\right)$ and $10 \%\left({ }^{*}\right)$.

* To control for the level differences in the discount rate, a dummy variable was included in all regressions with $\mathrm{DR}$ as regressor, being 1 if the respondents answered the questions with low money amounts and 0 if the respondents answered questions in which the money amounts were multiplied by 10 . 
Table 7c

Relationship between BMI and proxies for the discount rate for age groups $40-55$ by sex

\begin{tabular}{|c|c|c|c|c|c|c|c|c|c|}
\hline & \multicolumn{3}{|c|}{ ALL } & \multicolumn{3}{|c|}{ WOMEN } & \multicolumn{3}{|c|}{ MEN } \\
\hline & BMI & & & BMI & & & BMI & & \\
\hline & Coef & St.Dev. & Sign & Coef & St.Dev. & Sign & Coef & St.Dev. & Sign \\
\hline $\mathrm{DR}^{*}$ & 0.146 & 0.109 & & 0.079 & 0.193 & & 0.205 & 0.119 & * \\
\hline MANAGE & -1.074 & 0.198 & $* * *$ & -1.199 & 0.332 & $* * *$ & -0.953 & 0.228 & $* * *$ \\
\hline EXPENDITURES & -0.867 & 0.239 & *** & -1.186 & 0.414 & $* * *$ & -0.599 & 0.266 & $* *$ \\
\hline HOWMUCH & -0.483 & 0.207 & $* *$ & -0.811 & 0.335 & $* *$ & -0.129 & 0.250 & \\
\hline SAVE1 & -0.075 & 0.107 & & -0.203 & 0.184 & & 0.040 & 0.121 & \\
\hline SAVE2 & 0.196 & 0.090 & ** & 0.217 & 0.164 & & 0.180 & 0.097 & * \\
\hline SAVE3 & 0.234 & 0.121 & * & 0.199 & 0.243 & & 0.253 & 0.123 & ** \\
\hline SAVE4 & -0.248 & 0.141 & * & -0.273 & 0.239 & & -0.226 & 0.161 & \\
\hline SAVE5 & 0.125 & 0.117 & & 0.241 & 0.212 & & 0.039 & 0.126 & \\
\hline SAVE6 & 0.004 & 0.125 & & 0.107 & 0.235 & & -0.063 & 0.132 & \\
\hline RISK & 0.122 & 0.095 & & 0.139 & 0.160 & & 0.105 & 0.108 & \\
\hline FUTURE01 & 0.047 & 0.121 & & -0.045 & 0.202 & & 0.136 & 0.139 & \\
\hline FUTURE02 & 0.325 & 0.120 & $* * *$ & 0.399 & 0.211 & * & 0.266 & 0.132 & ** \\
\hline FUTURE03 & -0.011 & 0.119 & & -0.075 & 0.204 & & 0.046 & 0.134 & \\
\hline FUTURE04 & 0.113 & 0.118 & & 0.106 & 0.203 & & 0.119 & 0.132 & \\
\hline FUTURE05 & 0.103 & 0.130 & & -0.033 & 0.218 & & 0.237 & 0.150 & \\
\hline FUTURE06 & -0.002 & 0.126 & & -0.089 & 0.212 & & 0.079 & 0.143 & \\
\hline FUTURE07 & -0.053 & 0.145 & & -0.021 & 0.249 & & -0.082 & 0.164 & \\
\hline FUTURE08 & -0.031 & 0.141 & & 0.052 & 0.239 & & -0.109 & 0.160 & \\
\hline FUTURE09 & 0.095 & 0.132 & & 0.116 & 0.229 & & 0.076 & 0.148 & \\
\hline FUTURE10 & -0.141 & 0.129 & & -0.321 & 0.222 & & 0.014 & 0.145 & \\
\hline FUTURE11 & -0.071 & 0.126 & & -0.193 & 0.219 & & 0.031 & 0.140 & \\
\hline SPEND & -0.004 & 0.146 & & 0.140 & 0.250 & & -0.133 & 0.165 & \\
\hline PLAN & 0.616 & 0.107 & $* * *$ & 0.615 & 0.183 & $* * *$ & 0.616 & 0.121 & $* * *$ \\
\hline ASSETS $/ 100,000$ & -0.963 & 0.384 & ** & -2.458 & 1.090 & $* *$ & -0.648 & 0.336 & * \\
\hline LIABILITIES $/ 100,000$ & 0.077 & 0.394 & & -1.504 & 4.570 & & 0.094 & 0.314 & \\
\hline $\begin{array}{l}\text { ASSETS/(net income } \\
\text { per year*1000) }\end{array}$ & -0.381 & 0.669 & & -28.148 & 138.974 & & -0.381 & 0.591 & \\
\hline $\begin{array}{l}\text { LIABILITIES/(net } \\
\text { income per year*1000) }\end{array}$ & 340.782 & 215.059 & & 335.842 & 265.154 & & 364.589 & 459.535 & \\
\hline
\end{tabular}

Source: DNB household survey 2004 and supplementary survey 2004

Notes: The table contains the estimated coefficients for the proxies of the discount rate in an OLS regression with BMI of all respondents between the age of 40 and 55 and females and males separately as regressand, further including a full set of unreported dummies for all combinations of age and sex.

The indicated significance levels are $1 \%\left({ }^{* * *}\right), 5 \%\left({ }^{* *}\right)$ and $10 \%\left({ }^{*}\right)$.

- To control for the level differences in the discount rate, a dummy variable was included in all regressions with $\mathrm{DR}$ as regressor, being 1 if the respondents answered the questions with low money amounts and 0 if the respondents answered questions in which the money amounts were multiplied by 10 . 
Table 7d

Relationship between BMI and proxies for the discount rate for age groups $55+$ by sex

\begin{tabular}{lllllll}
\multicolumn{1}{c}{ ALL } & \multicolumn{2}{c}{ WOMEN } & \multicolumn{2}{c}{ MEN } \\
BMI & \multicolumn{3}{c}{ BMI } & BMI & \\
Coef & St.Dev. Sign & Coef & St.Dev. Sign & Coef & St.Dev. Sign
\end{tabular}

\begin{tabular}{|c|c|c|c|c|c|c|c|c|c|}
\hline $\mathrm{DR}^{*}$ & 0.021 & 0.083 & & -0.133 & 0.155 & & 0.113 & 0.094 & \\
\hline MANAGE & -0.289 & 0.177 & & -0.327 & 0.291 & & -0.252 & 0.220 & \\
\hline EXPENDITURES & -0.081 & 0.199 & & -0.247 & 0.361 & & 0.030 & 0.230 & \\
\hline HOWMUCH & -0.336 & 0.198 & & -0.288 & 0.329 & & -0.372 & 0.244 & \\
\hline SAVE1 & -0.105 & 0.084 & & -0.221 & 0.149 & & -0.022 & 0.098 & \\
\hline SAVE2 & 0.010 & 0.071 & & -0.124 & 0.140 & & 0.077 & 0.077 & \\
\hline SAVE3 & 0.086 & 0.101 & & -0.015 & 0.242 & & 0.116 & 0.103 & \\
\hline SAVE4 & -0.127 & 0.105 & & -0.286 & 0.180 & & 0.002 & 0.127 & \\
\hline SAVE5 & 0.058 & 0.089 & & 0.042 & 0.187 & & 0.066 & 0.095 & \\
\hline SAVE6 & 0.083 & 0.100 & & 0.116 & 0.209 & & 0.069 & 0.107 & \\
\hline RISK & -0.012 & 0.074 & & -0.323 & 0.169 & & -0.042 & 0.084 & \\
\hline FUTURE01 & -0.195 & 0.095 & ** & -0.305 & 0.195 & * & -0.104 & 0.112 & \\
\hline FUTURE02 & -0.186 & 0.090 & ** & -0.230 & 0.162 & & -0.156 & 0.105 & \\
\hline FUTURE03 & 0.402 & 0.087 & $* * *$ & 0.522 & 0.167 & $* * *$ & 0.335 & 0.098 & $* * *$ \\
\hline FUTURE04 & 0.116 & 0.083 & & -0.014 & 0.161 & & 0.186 & 0.092 & $* *$ \\
\hline FUTURE05 & 0.012 & 0.103 & & -0.005 & 0.184 & & 0.023 & 0.119 & \\
\hline FUTURE06 & -0.167 & 0.099 & * & -0.416 & 0.181 & ** & -0.010 & 0.113 & \\
\hline FUTURE07 & -0.105 & 0.108 & & 0.149 & 0.195 & & -0.278 & 0.124 & ** \\
\hline FUTURE08 & -0.268 & 0.098 & $* * *$ & -0.398 & 0.181 & ** & -0.188 & 0.112 & \\
\hline FUTURE09 & 0.035 & 0.095 & & -0.167 & 0.168 & & 0.182 & 0.111 & \\
\hline FUTURE10 & 0.045 & 0.092 & & -0.009 & 0.174 & & 0.077 & 0.104 & \\
\hline FUTURE11 & 0.145 & 0.089 & & 0.000 & 0.164 & & 0.238 & 0.102 & ** \\
\hline SPEND & 0.075 & 0.124 & & 0.085 & 0.234 & & 0.069 & 0.139 & \\
\hline PLAN & 0.211 & 0.094 & ** & 0.290 & 0.169 & * & 0.157 & 0.109 & \\
\hline ASSETS/100,000 & -0.076 & 0.141 & & 0.089 & 0.303 & & -0.139 & 0.150 & \\
\hline LIABILITIES/100,000 & 1.481 & 1.167 & & 2.632 & 2.349 & & 0.955 & 1.281 & \\
\hline $\begin{array}{l}\text { ASSETS/(net income } \\
\text { per year*1000) }\end{array}$ & 0.319 & 0.594 & & 7.247 & 14.841 & & 0.305 & 0.535 & \\
\hline $\begin{array}{l}\text { LIABILITIES/(net } \\
\text { income per year*1000) }\end{array}$ & 15.197 & 42.924 & & 7.024 & 56.325 & & 40.693 & 78.348 & \\
\hline
\end{tabular}

Source: DNB household survey 2004 and supplementary survey 2004

Notes: The table contains the estimated coefficients for the proxies of the discount rate in an OLS regression with BMI of all respondents aged 55 or older and females and males separately as regressand, further including a full set of unreported dummies for all combinations of age and sex.

The indicated significance levels are $1 \%\left({ }^{* * *}\right), 5 \%\left({ }^{* *}\right)$ and $10 \%\left({ }^{*}\right)$.

* To control for the level differences in the discount rate, a dummy variable was included in all regressions with DR as regressor, being 1 if the respondents answered the questions with low money amounts and 0 if the respondents answered questions in which the money amounts were multiplied by 10 .

The human capital theory predicts that the individual discount rate will be negatively related to educational investments and consequently to income. To investigate the robustness of the link between the proxies MANAGE and PLAN and BMI, we include dummies for educational 
achievement and income in these regressions. As in previous regressions, a full set of age and sex dummies is included. Table $8 \mathrm{a}$ and $8 \mathrm{~b}$ provide the estimates. For both proxies we find a significant negative parameter for university degree. The effect of the time discount proxies reduces slightly from -.785 to -.655 for MANAGE and from .489 to .468 for PLAN, but both parameters remain significant at the 1-percent level.

The size of the cross-sectional relationship between these proxies for time discounting and BMI will be downward biased due to measurement error. To get a more adequate estimation of the magnitude to the time discounting effects, we estimate parameters with 2SLS, using PLAN as instrument for MANAGE and vice versa, and again saturating the model with age and sex dummies. The 2SLS estimations exceed the OLS results, as expected. The negative coefficient for MANAGE increases from -.785 to -2.006 (t-value: -7.462 ) and the effect of PLAN increases from .489 to .968 (t-value: 6.704 ). This implies that to fully explain a 1.35-point increase in BMI for the period 1995-2004, a decrease in the average of MANAGE of .672 and an increase in the average of PLAN of 1.395 is needed.

So, although the cross-sectional relationship between time discounting and BMI is rather sensitive to the choice of a time discounting proxy, this relationship does not reflect pure effects of educational attainment or income.

Table 8a

Relationship between BMI and MANAGE as proxy for the discount rate, controlled for income and education levels

B Std.
Error

Constant

MANAGE

Low vocational degree

High school

Intermediate vocational degree

High vocational degree

University degree

Net income per year $/ 100,000$

Age + Sex dummies
$29.339 \quad 1.993$

$-0.655 \quad 0.123$

$0.423 \quad 0.336$

$-0.543 \quad 0.399$

$0.169 \quad 0.359$

$-0.104 \quad 0.342$

$-0.925 \quad 0.417$

$-0.250 \quad 0.504$

Yes

Source: DNB household survey 2004 and supplementary survey 2004

Notes: The table contains the estimated coefficients for MANAGE, dummies for levels of education obtained and net annual income in an OLS regression with BMI of all respondents as regressand, further including a full set of unreported dummies for all combinations of age and sex.

The indicated significance levels are $1 \%\left({ }^{* * *}\right), 5 \%\left({ }^{* *}\right)$ and $10 \%\left({ }^{*}\right)$. 
Table $8 b$

Relationship between BMI and PLAN as proxy for the discount rate, controlled for income and education levels

\begin{tabular}{|c|c|c|c|}
\hline & B & $\begin{array}{l}\text { Std. } \\
\text { Error }\end{array}$ & \\
\hline Constant & 25.715 & 1.929 & *** \\
\hline MANAGE & 0.468 & 0.066 & $* * *$ \\
\hline Low vocational degree & 0.494 & 0.333 & \\
\hline High school & -0.536 & 0.396 & \\
\hline Intermediate vocational degree & 0.179 & 0.356 & \\
\hline High vocational degree & -0.039 & 0.340 & \\
\hline University degree & -0.850 & 0.414 & $* *$ \\
\hline Net income per year $/ 100,000$ & -0.575 & 0.494 & \\
\hline Age + Sex dummies & Yes & & \\
\hline
\end{tabular}

Source: $\quad$ DNB household survey 2004 and supplementary survey 2004

Notes: The table contains the estimated coefficients for PLAN, dummies for levels of education obtained and net annual income in an OLS regression with BMI of all respondents as regressand, further including a full set of unreported dummies for all combinations of age and sex.

The indicated significance levels are $1 \%\left({ }^{* * *}\right), 5 \%\left({ }^{* *}\right)$ and $10 \%\left({ }^{*}\right)$.

\section{The relationship between time discounting and BMI over time}

An important issue is whether this correlation between the discount rate and BMI is able to explain the rise in BMl that the Netherlands has experienced in the past decade. To give this hypothesis the best chance, we will discuss the development of the link between time discounting and BMI on the basis of the proxies PLAN, and MANAGE. ${ }^{3}$

Figure 4-5 provide the development of these proxies for time discounting over time. Again, the range at the vertical axis has been set equal to one standard deviation of the variable concerned, with the average for all years in the center of the graph. The figures reveal that the relationship between time discounting and BMI cannot explain the marked increase in body mass over the time period investigated. The small fluctuations in the discount proxies seem to be more related to business cycles. There is no clear downward trend in MANAGE. A linear regression analysis explaining the average value of MANAGE with a time trend gives a coefficient of -.008 (s.d. .006). This insignificant decrease implies a change of $8 \%$ over the whole period. This is one tenth of the change that is needed to explain the increase in BMI. The largest difference between the averages in two years (1995 and 1998) is only 24 percent of the size needed to explain the upward trend in BMI. Also PLAN does not have a clear upward pattern and the changes are of insufficient size to explain the trend in BMI. The time trend coefficient of a linear regression is .009 (s.d. .011). This increase can explain only

3. Analyses based on other proxies of time discounting related to BMI in the cross section, provide similar results. 
Figure 4

Development of the scores on MANAGE-variable as a proxy for time discounting, 1995-2004

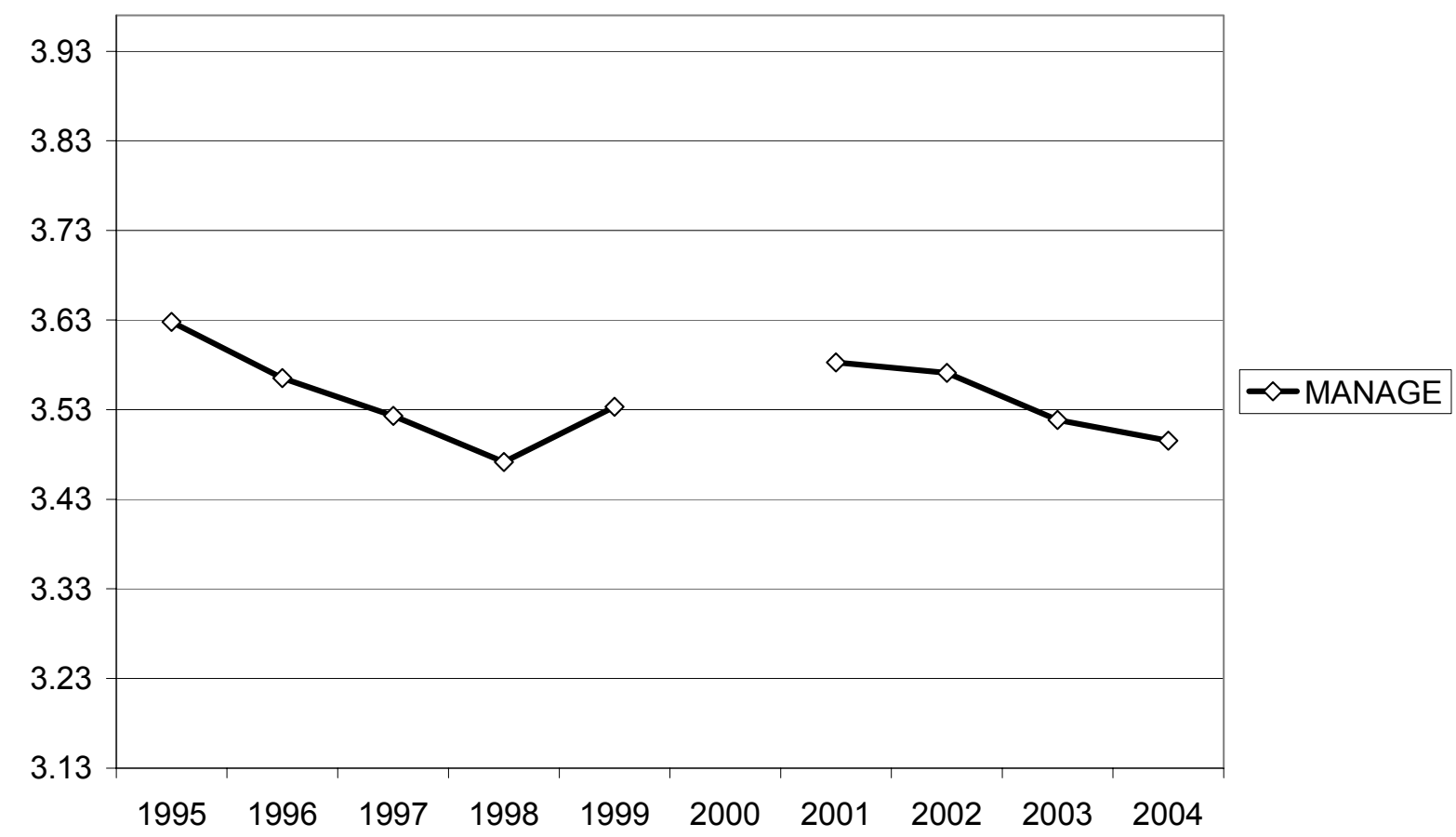

Source: DNB household survey 1995-1999, 2001-2004

Note: $\quad$ The scale of the vertical axis is determined by the mean total score over the years on BMI of women of all age groups together \pm 0.5 times its standard deviation.

Figure 5

Development of the scores on PLAN-variable as a proxy for time discounting, 1995-2004

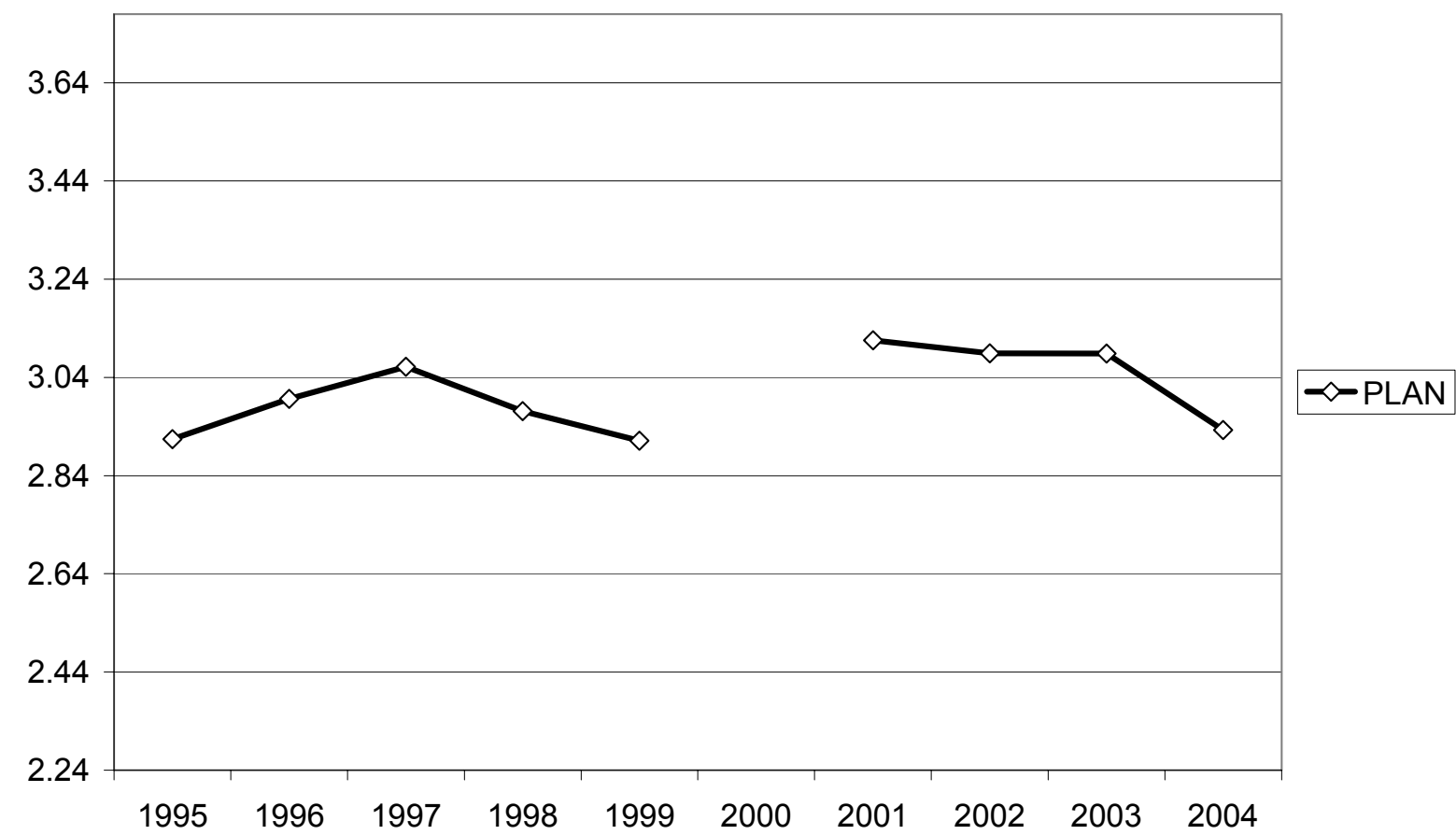

Source: DNB household survey 1995-1999, 2001-2004

Note: $\quad$ The scale of the vertical axis is determined by the mean total score over the years on BMI of women of all age groups together \pm 0.5 times its standard deviation. 
$6 \%$ of the increase in BMI. The largest difference in averages (1995 and 2001) explains 15 percent of the 1.35-point increase in BMI. Similar patterns are found when we investigate the proxies for specific age and sex groups in the data. There might of course be a delay between developments in the average individual discount rate and BMI. It is not very likely, however, that such a lag takes the full length of the 10 years for which we have data available.

Figure 6

Development of coefficients for MANAGE in annual regressions explaining BMI, 1995-2004

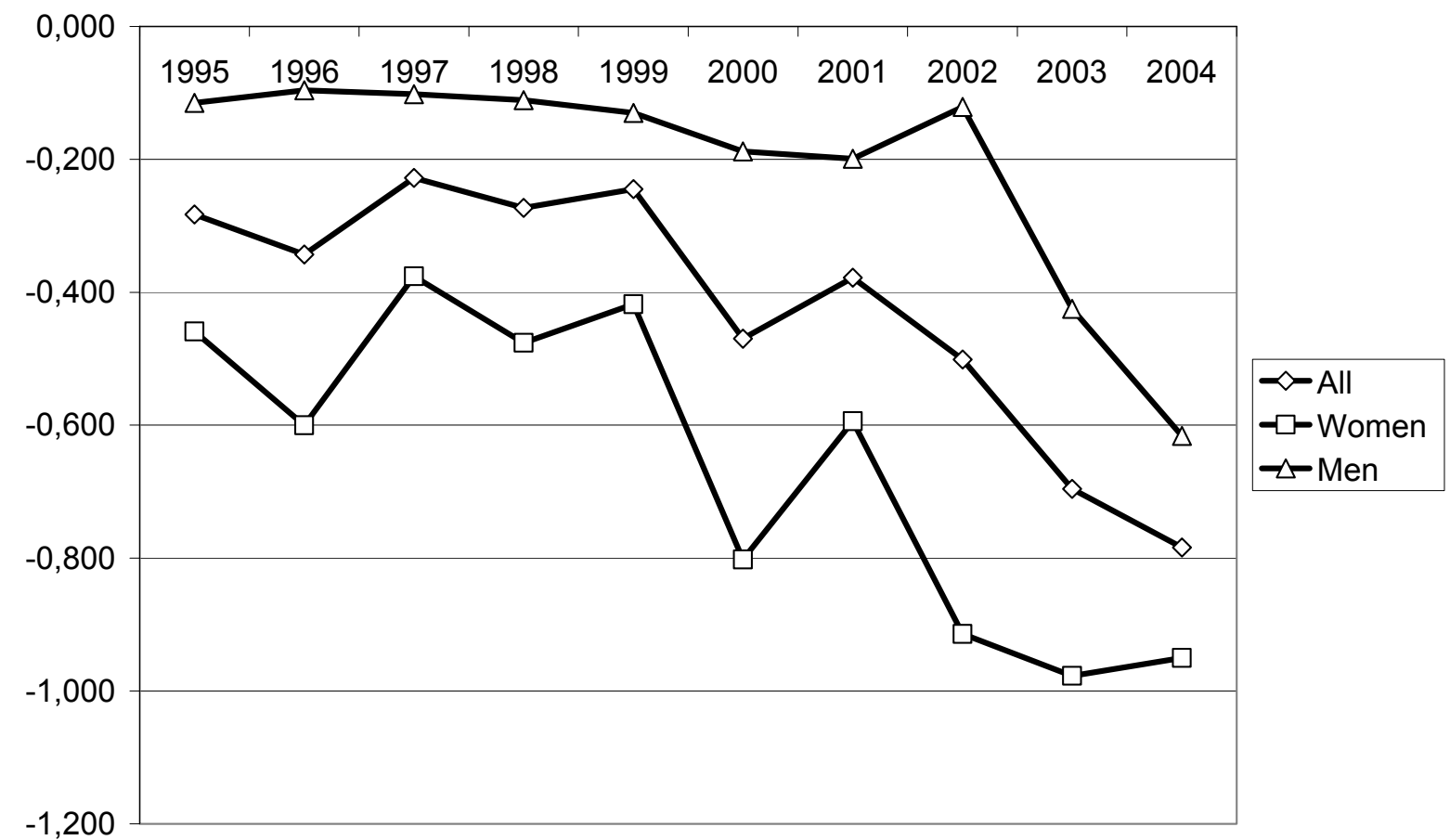

Source: DNB household survey 1995-1999, 2001-2004

Note: The graph depicts all estimated coefficients for MANAGE in an OLS regression with BMI for all respondents and males and females separately as regressand, further including a full set of dummies for all combinations of age and sex.

This leaves us with the question whether there has been a constant shift in BMI over time for people with different discount values, or whether the increase in BMI has been larger among high discounters than among low discounters. We estimate the relationship between the two proxies and BMI for all years. Figure 6 and 7 show the development of the estimated parameters for time discounting. Both figures reveal that the correlation between time discounting and BMI has increased over time: high discounters gained more weight than low discounters. This was more so for women than for men. This implies that whatever has been the cause of the increase in BMI, the change has not shifted the "optimal" BMI for all people with an equal amount. Potential explanations for the increase in average BMI are thus interacting with the individual discount rate. In the specification of the model in Section 2 changes in the price of calories would not generate such an interaction effect, but shifts in the relative price of substitutes and complements would increase the gap between the BMI 
of low and high discounters. ${ }^{4}$ Figure 8 and 9 depict this diverging trend in an alternative way. We split the sample in two parts: one group representing high discounters (PLAN larger than 4 and MANAGE less than 3) and the other group low discounters. The graphs clearly show a steady increase in the BMI of the high discounters, while the BMI of the low discounters remains more stable.

Figure 7

Development of coefficients for PLAN in annual regressions explaining BMI, 1995-2004

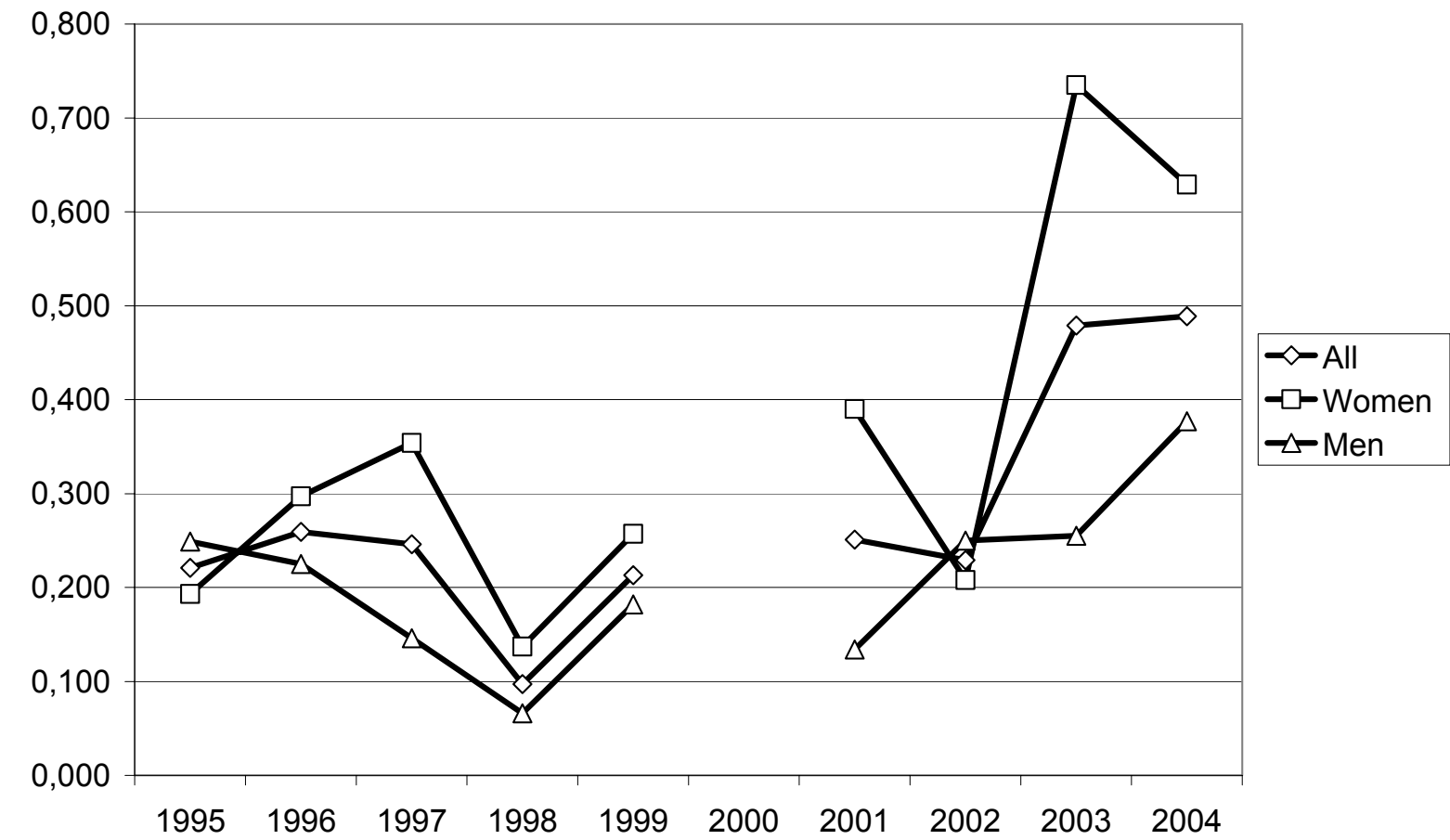

Source: DNB household survey 1995-1999, 2001-2004

Note: $\quad$ The graph depicts all estimated coefficients for PLAN in an OLS regression with BMI for all respondents and females and males separately as regressand, further including a full set of dummies for all combinations of age and sex.

4. A model in which the utility in the second period is non-linearly related to $A$, could also generate such interaction effects. 
Figure 8

BMI for high and low discounters (based on MANAGE variable), 1995-2004

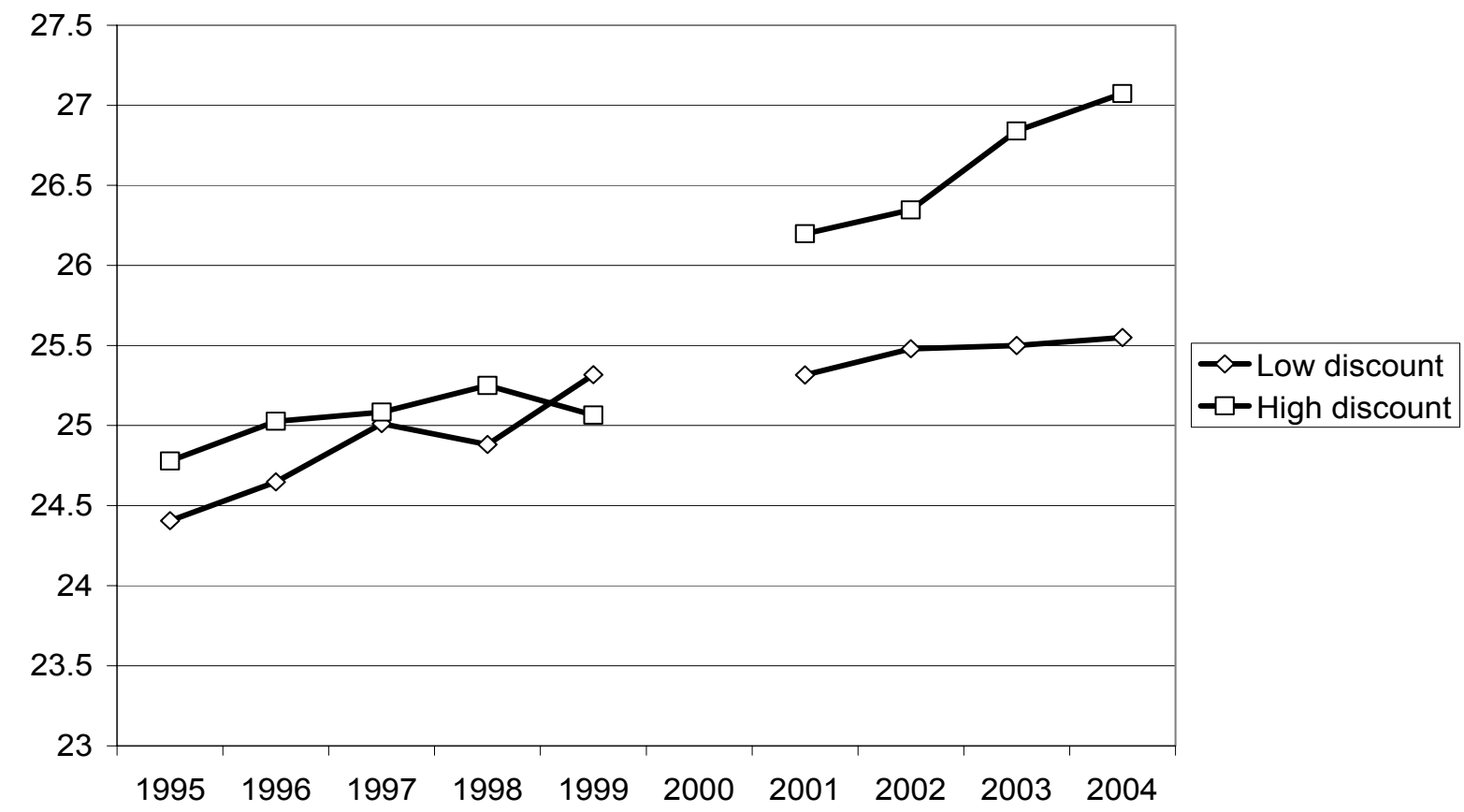

Source: DNB household survey 1995-1999, 2001-2004

High discounters have been defined as values for MANAGE less than 3.

Note: $\quad$ The scale of the vertical axis is determined by the mean total score over the years on BMI of women of all age groups together \pm 0.5 times its standard deviation.

Figure 9

BMI for high and low discounters (based on PLAN variable), 1995-2004.

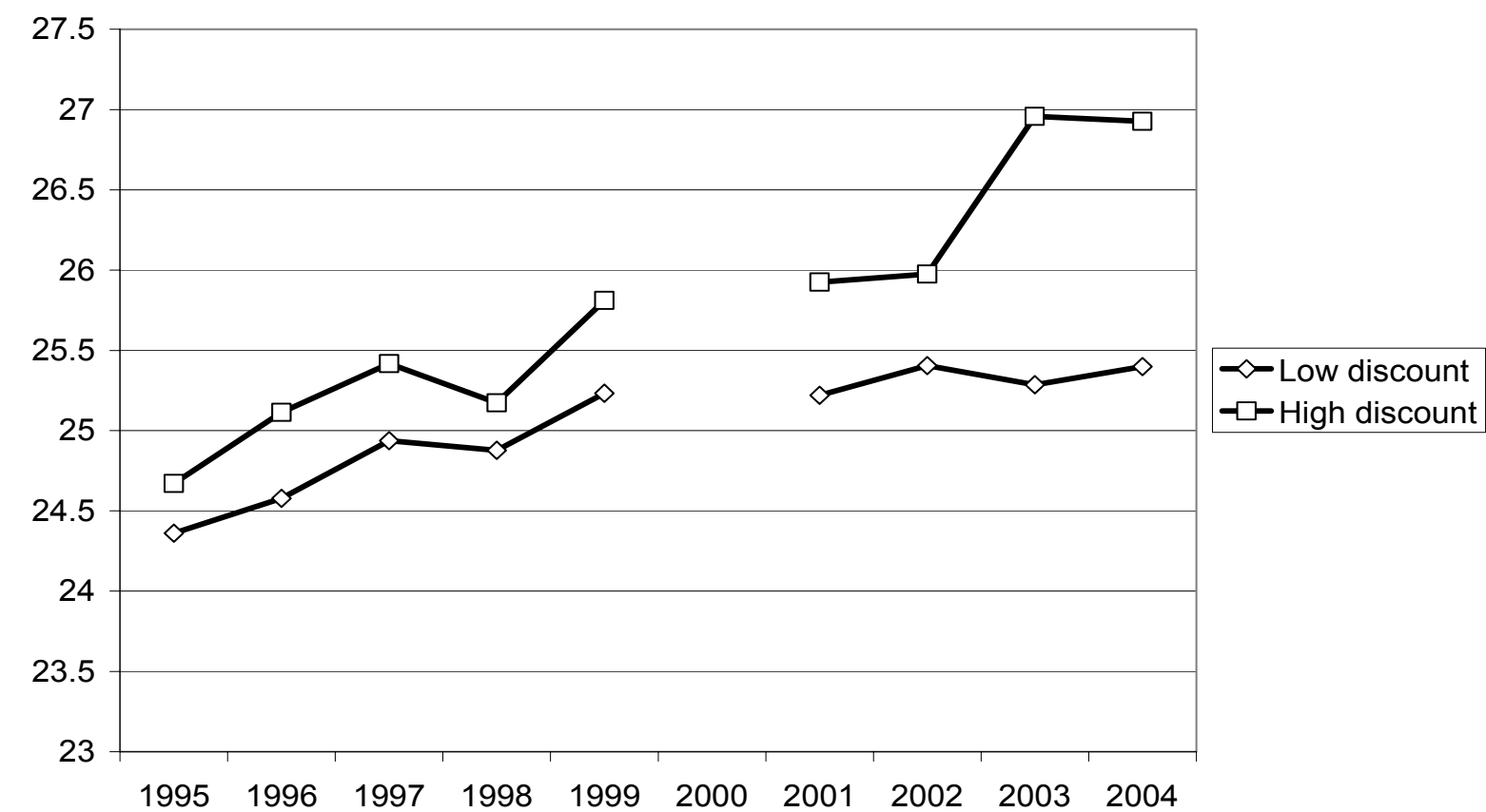

Source: DNB household survey 1995-1999, 2001-2004

High discounters have been defined as values for PLAN larger than 4 .

Note: $\quad$ The scale of the vertical axis is determined by the mean total score over the years on BMI of women of all age groups together \pm 0.5 times its standard deviation. 


\section{Discussion and conclusions}

In this paper we have analyzed (i) whether differences in BMI between people at a certain moment of time are related to the individual discount rate, and (ii) whether a positive trend in time discounting can account for the increase of BMI over time. To analyze this question, we have used data from a survey among a sample of the Dutch population, for the period 19952004, which contains not only information about body weight and length, but also has a very large set of questions concerning the financial situation and attitude of the respondents. On the basis of the 2004 data, we have investigated the link between the discount rate and BMI, and the validity of a wide range of financial questions as proxies for the discount rate. Using the validated proxies, we have investigated the development of the discount rate and its link with BMI over time.

Our main findings are that differences in BMI between people in a specific year in the sample are related to some of our measures of the individual discount rate. Especially measures that are related to the ability to manage expenditures are correlated with BMI. Comparing different years, however, it turns out that the average individual discount rate did not change from 1995 - 2004. The upward trend in BMI can therefore not be accounted for by an increase in the individual discount rate. We find that with the increase of BMI the difference in BMI between low and high discounters has also increased, i.e. BMI may not have increased because the average discount rate increased but because high discounters gained more weight.

On the basis of the basic model in Section 2 the only alternative explanation left for a rise in BMI would be a fall in the price of calorie-rich food. Cutler, Glaeser and Shapiro (2003) provide convincing evidence for this fall in the price. This price trend, however, does not explain the growing dispersion in BMl between high and low discounters, nor is it able to explain the weak cross-sectional relationship between time discounting and BMI. It also leaves unexplained the remarkable differences between sex and age groups with respect to this link between time discounting and BMI.

We believe that for future research it is important to look in greater depth at the substitutability and complementarity between food consumption and other forms of risky behavior and investments in human capital. The extended model in Section 2 has shown that such interaction can influence the discount rate-BMI relationship to a great extent. Both cross-sectional data and time series evidence provide examples to illustrate such potential interactions. First, a regression explaining BMI with apart from the usual variables (age-sex dummies) also the answer to the question "In my work people take care I get tasks of which I can learn a lot", gives a significant parameter of .197 (st.dev=.087). A potential explanation for this finding is that people who face good opportunities to work on their career, put less weight on future health, when the stress of working hard can be compensated by extra food consumption. A time-series example is provided by the data about smoking. Figure 10 depicts the development of smoking in the Netherlands in the past 10 years. Developments in the discount rate alone can never account for both this trend and the trend in BMI. Various policy measures to reduce smoking have clearly increased the price of smoking. Our 
hypothesis is that reductions in smoking behavior could also have caused the increase in BMI when smoking and eating are substitutes in period's 1 utility function. Since both behaviors can help to reduce distress, such substitutability seems not to be unlikely. We therefore think that such interactions in behavior provide interesting avenues for further research concerning the developments of obesity.

Figure 10

The development of smoking rates, 1995-2004

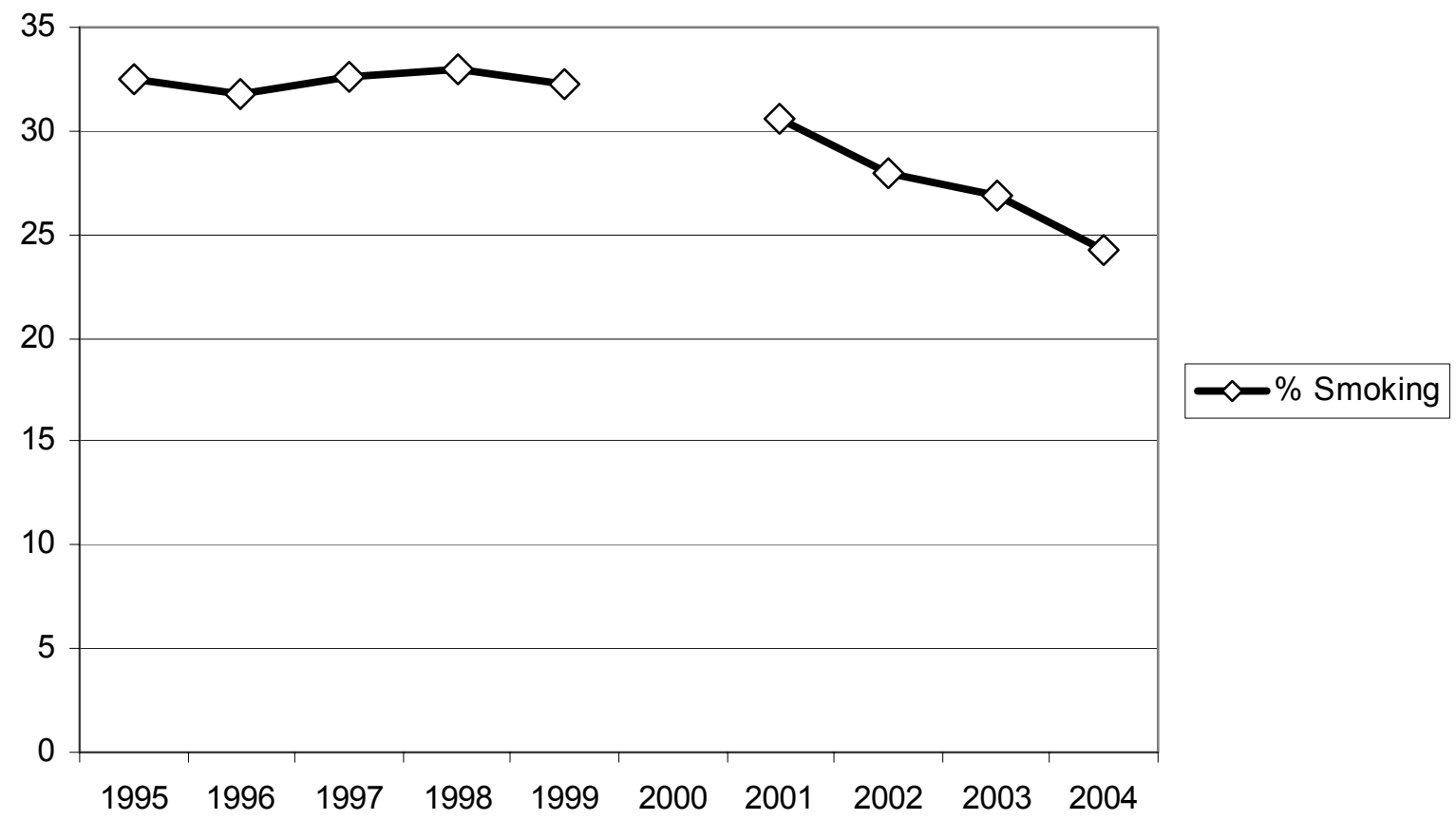

Source: DNB household survey 1995-1999, 2001-2004

\section{Literature}

Becker, G., 1964, Human Capital, A Theoretical and Empirical Analysis, With Special Reference to Education (NY: Columbia University Press).

Becker, G. and C. Mulligan, 1997, The Endogenous Determination of Time Preference, Quarterly Journal of Economics 112(3), 729-758.

Bickel, W., A. Odum and G. Madden, 1999, Impulsivity and Cigarette Smoking: Delay Discounting in Current, Never, and Ex-Smokers, Psychopharmacology 146 (4), 447-454.

Blaylock, J., S. Smallwood, K. Kassel, J. Variyam and L. Aldrich, 1999, Economics, Food Choices, and Nutrition, Food Policy 24, 269-286.

Borghans, L. and B. Golsteyn, 2005, Imagination, Time Discounting and Human Capital Investment Decisions, Unpublished working paper, University of Maastricht, Maastricht.

Burton, S. and S. Tiffany, 1997, The Effects of Alcohol Consumption on Craving to Smoke, Addiction 92, 15-26.

Cawley, J., 2000, Body Weights and Women's Labor Market Outcomes, NBER Working Paper No. 7841. 
Cawley, J., S. Markowitz and J. Tauras, 2003, Lighting Up and Slimming Down: The Effects of Body Weight and Cigarette Prices on Adolescent Smoking Initiation, NBER Working Paper No. 9651.

Chapman, G. and E. Coups, 1999, Time Preferences and Preventive Health Behavior: Acceptance of the Influenza Vaccine, Medical Decision Making 19, 307-314.

Chapman, G. and A. Elstein, 1995, Valuing the Future, Temporal Discounting of Health and Money, Medical Decision Making 15(4), 373-386.

Chapman, G., R. Nelson and D. Hier, 1999, Familiarity and Time Preferences: Decision Making About Treatments for Migraine Headaches and Crohn's Disease, J. Exper. Psych.: Applied 5(1), 17-34.

Chevalier, A. and I. Walker, 1999, Further Results on the Returns to Education in the UK, Unpublished working paper, University of Warwick.

Cutler, D. and E. Glaeser, 2005, What Explains Differences in Smoking, Drinking and Other HealthRelated Behaviors, NBER Working Paper No. 11100.

Cutler, D., E. Glaeser and J. Shapiro, 2003, Why Have Americans Become More Obese?, NBER Working Paper No. 9446.

DellaVigna, S. and M.D. Paserman, 2004, Job Search and Impatience, Journal of Labor Economics, forthcoming.

Evans, W. and E. Montgomery, 1994, Education and Health: Where There is Smoke, There is an Instrument, NBER Working Paper No. 4949.

Fersterer, J. and R. Winter-Ebmer, 2003, Smoking, Discount Rates, and Returns to Education, Economics of Education Review 22, 561-566.

Fishburn, P., 1970, Utility Theory and Decision Making (New York: Wiley).

Flegal, K. M. Carroll, R. Kuczmarksi and C. Johnson, 1998, Overweight and Obesity Trends in the United States: Prevalence and Trends, 1960-1994, International Journal of Obesity and Related Metabolic Disorders 22(1), 39-47.

Frederick, S., 2005, Cognitive Reflection, Intelligence and Decision Making: How Much Does the Ball Cost?, Unpublished working paper.

Frederick, S., G. Loewenstein and T. O'Donoghue, 2002, Time Discounting and Time Preference: A Critical Review, Journal of Economic Literature XL, 351-401.

Fuchs, V., 1982, Time Preference and Health: An Exploratory Study, in: V. Fuchs (Ed.), Economic Aspects of Health, University of Chicago Press, Chicago, pp. 93-120.

Gafni, A. and G. Torrance, 1984, Risk Attitude and Time Preference in Health, Management Science 30(4), Risk Analysis, 440-451.

Green, D., K. Jacowitz, D. Kahneman and D. McFadden, 1998, Referendum Contingent Valuation, Anchoring, and Willingness to Pay for Public Goods, Resource Energy Economics 20, 85-116.

Grossman, M., 1972, On the Concept of Health Capital and the Demand for Heath, Journal of Political Economy 80(2), 223-55.

Gulliver, S., 1995, Interrelationships of Smoking and Alcohol Dependence, Use and Urges to Use, Journal of Studies on Alcohol 56, 202-206.

Hersch, J., 1996, Smoking, Seat Belts, and Other Risky Consumer Decisions: Differences by Gender and Race, Managerial and Decision Economics 17, 471-481.

Hersch, J., 2000, Gender, Income Levels, and the Demand for Cigarettes, Journal of Risk and Uncertainty 21(2), 263-282. 
Hersch, J. and W. K. Viscusi, 1990, Cigarette Smoking, Seatbelt Use and Differences in Wage-Risk Tradeoffs, Journal of Human Resources 25(2), 202-227.

Kirby, K., N. Petry and W. Bickel, 1999, Heroin Addicts Have Higher Discount Rates For Delayed Rewards Than Non-Drug-Using Controls, Journal of Experimental Psychology: General 128, 7887.

Komlos, J. and M. Baur, 2004, From the Tallest to (one of) the Fattest: The Enigmatic Fate of the American Population in the $20^{\text {th }}$ Century, Economics and Human Biology 2(1), 57-74.

Komlos, J., P. Smith and B. Bogin, 2004, Obesity and the Rate of Time Preference: Is There a Connection? Journal of Biosocial Science 36(2), 209-219.

Koopmans, T., 1960, Stationary Ordinal Utility and Impatience, Econometrica 28, 287-309.

Lakdawalla, D. and T. Philipson, 2002, The Growth of Obesity and Technological Change: A Theoretical and Empirical Examination, NBER Working Paper No. 8946.

Lancaster, K., 1963, An Axiomatic Theory of Consumer Time Preference, International Economic Review 4, 221-231.

Levine, P., T. Gustafson and A. Velenchik, 1997, More Bad News for Smokers? The Effects of Cigarette Smoking on Labor Market Outcomes, Industrial and Labor Relations Review 50(3), 493509.

Levy, A., 2002, Rational Eating: Can It Lead to Overweightness Or Underweightness? Journal of Health Economics 21, 887-899.

Loewenstein, G., 1992, The Fall and Rise of Psychological Explanation in the Economics of Intertemporal Choice, in: Loewenstein, G. and Elster, J. (Eds.), Choice Over Time, New York: Russell Sage, pp. 3-34.

Madden, G., N. Petry, G. Badger and W. Bickel, 1997, Impulsive and Self-Control Choices in OpiodDependent Patients and Non-Drug-Using Control Participants: Drug and Money Rewards, Experimental and Clinical Psychopharmacology 5, 256-262.

Mokdad, A., M. Serdula, W. Dietz, B. Bowman, J. Marks and J. Koplan, 1999, The Spread of the Obesity Epidemic in the United States, 1991-1998, Journal of the American Medical Association 282(16), 1519-1522.

Mulligan, C., 2005, A Logical Economist's argument against Hyperbolical Discounting, Unpublished working paper, University of Chicago.

Munasinghe, L. and N. Sicherman, 2000, Why Do Dancers Smoke? Time Preference, Occupational Choice, and Wage Growth, NBER Working Paper No. 7542.

National Gambling Impact Study Commission. National Gambling Impact Study: Final

Report, 1999, http://govinfo.library.unt.edu/ngisc/reports/finrpt.html.

Ogden, C., C. Frayer, M. Carroll and K. Flegal, 2004, Mean Body Weight, Height and Body Mass Index, United States 1960-2000, Advance Data From Vital and Health Statistics No. 347, Hyattsville MD, National Center for Health Statistics.

Parker, J., 1999, Spendthrifts in America? On two decades of decline in the U.S. saving

rate," in Bernanke, B., Rotemberg, J. (Eds.), NBER Macroeconomics Annual

1999, MIT Press, Boston, pp. 317-370.

Picone, G., F. Sloan and J. Trogdon, 2004, The Effect of the Tobacco Settlement and Smoking Bans on Alcohol Consumption, Health Economics 13, 1063-1080. 
Philipson, T., 2001, The World-Wide Growth in Obesity: An Economic Research Agenda, Health Economics 10(1), 1-7.

Philipson, T, and R. Posner, 1999, The Long-Run Growth in Obesity as a Function of Technological Change, John M. Olin Program in Law \& Economics Working Paper No. 78, University of Chicago Law School.

Popkin, B. and C. Doak, 1998, The Obesity Epidemic is a Worldwide Phenomenon, Nutrition Reviews 56(4), 106-114.

Rachlin, H., A. Raineri, D. Cross, 1991, Subjective Probability and Delay, J. Exp. Anal. Behav. 55, 233-244.

Ruhm C., 2000, Are Recessions Good for Your Health? Quarterly Journal of Economics 115(2), 617650.

Sykes, D., A. Evans and E. McCrum, 1990, Psychological Risk Profile of Smokers Compared With Non-Smokers and Past Smokers: A Population Based Study, in: Durston, B. and Jamrozik, K. (Eds.), Proceedings of the $7^{\text {th }}$ World conference on Tobacco and Health, Health Department of Western Australia, Perth.

Samuelson, P., 1937, A Note on Measurement of Utility, Review of Economic Studies 4, 155-161.

Thaler, R., 1985, Mental Accounting and Consumer Choice, Management Science 4, 199-214.

Viscusi, W.K. and J. Hersch, 2001, Cigarette Smoking as Job Risk Takers, Review of Economic and Statistics 83(2), 269-280.

Vuchinich, R. and C. Simpson, 1998, Hyperbolic Temporal Discounting in Social Drinkers and Problem Drinkers, Experimental and Clinical Psychopharmacology 6, 292-305. 